Article

\title{
Multi-Scale Hydrologic Sensitivity to Climatic and Anthropogenic Changes in Northern Morocco
}

\author{
Adam Milewski ${ }^{1, *(\mathbb{O})}$, Wondwosen M. Seyoum ${ }^{2}$, Racha Elkadiri $^{3}$ and Michael Durham ${ }^{1}$ \\ 1 Water Resources \& Remote Sensing Laboratory (WRRS), Department of Geology, University of Georgia, \\ 210 Field Street, 306 Geography-Geology Building, Athens, GA 30602, USA; durham@uga.edu \\ 2 Department of Geography, Geology, and the Environment, Illinois State University, Normal, IL 61790, USA; \\ wmseyou@ilstu.edu \\ 3 Department of Geosciences, Middle Tennessee State University, Murfreesboro, TN 37132, USA; \\ racha.elkadiri@mtsu.edu \\ * Correspondence: milewski@uga.edu
}

Received: 1 November 2019; Accepted: 23 December 2019; Published: 27 December 2019

check for updates

\begin{abstract}
Natural and human-induced impacts on water resources across the globe continue to negatively impact water resources. Characterizing the hydrologic sensitivity to climatic and anthropogenic changes is problematic given the lack of monitoring networks and global-scale model uncertainties. This study presents an integrated methodology combining satellite remote sensing (e.g., GRACE, TRMM), hydrologic modeling (e.g., SWAT), and climate projections (IPCC AR5), to evaluate the impact of climatic and man-made changes on groundwater and surface water resources. The approach was carried out on two scales: regional (Morocco) and watershed (Souss Basin, Morocco) to capture the recent climatic changes in precipitation and total water storage, examine current and projected impacts on total water resources (surface and groundwater), and investigate the link between climate change and groundwater resources. Simulated (1979-2014) potential renewable groundwater resources obtained from SWAT are $\sim 4.3 \times 10^{8} \mathrm{~m}^{3} / \mathrm{yr}$. GRACE data (2002-2016) indicates a decline in total water storage anomaly of $\sim 0.019 \mathrm{~m} / \mathrm{yr}$., while precipitation remains relatively constant through the same time period (2002-2016), suggesting human interactions as the major underlying cause of depleting groundwater reserves. Results highlight the need for further conservation of diminishing groundwater resources and a more complete understanding of the links and impacts of climate change on groundwater resources.
\end{abstract}

Keywords: climate change; groundwater; remote sensing; anthropogenic

\section{Introduction}

Water scarcity is among the main challenges of the twenty-first century. Approximately two billion people of the world's population live in areas suffering from water shortages or approaching this situation [1]. Population increase and climate change are among the drivers expected to significantly escalate the stress on water resources and groundwater aquifers [2,3]. This situation calls for strong, meticulous efforts to manage this resource, especially in water-scarce regions [4,5]. The Middle East and North Africa (MENA) region is water-scarce, and population growth and water usage, particularly for irrigation, have contributed to water stress through withdrawals in excess of annual renewable supplies. Per-capita water resources in the region averaged $606 \mathrm{~m}^{3} /$ person/yr. in 2005, but were unevenly distributed, with all countries other than Iraq, Syria, and Lebanon having $<1000 \mathrm{~m}^{3} /$ person/yr. [6]. In addition, the allocation of transboundary water resources poses political challenges, such as in the Nile, Tigris-Euphrates, and Jordan river basins, the Nubian aquifer system of northeast Africa, and the Disi aquifer system in Jordan and Saudi Arabia [6]. In Morocco, there are currently three 
major strategic plans involving water: the National Water Plan, the National Water Savings Plan, and the Green Morocco Plan (PMV), each of which has a focus on agriculture [6]. However, throughout the MENA region and worldwide, there is still a lack of quantitative understanding of hydrology, hydrogeology, and the possible impacts of climate change on water resources. In many vulnerable areas of the world, water resource assessment is hampered by the scarcity or unavailability of relevant datasets [4,7-11]. The monitoring of water resources typically requires extensive networks of ground-based stations $[12,13]$. Data collection and analysis at this level is typically not available in vulnerable regions or developing countries. Furthermore, in-situ measurements cannot fully capture the complexity and variability of the water cycle, as they are often only point measurements [14]. Fortunately, recent advances in remote sensing hold promise for addressing these inadequacies, offering numerous opportunities for hydrologists to assess components of the water cycle at multiple spatial and temporal scales, opportunities that include missions and sensors for measuring precipitation (e.g., the Global Precipitation Measurement [GPM] and the Tropical Rainfall Measuring Mission [TRMM]), and assessing groundwater variability (e.g., the Gravity Recovery and Climate Experiment [GRACE]). The integration and evaluation of satellite remote sensing data into hydrologic models (e.g., SWAT) has been successfully applied to data scarce regions to examine hydrologic fluxes and variability [4,9], climatic and anthropogenic impacts [15-17], streamflow [18], and groundwater withdrawal and variability [19]. Xu et al. (2014) [20] detailed the progress in such an endeavor. Satellite remote sensing datasets have been increasingly utilized for hydrologic measurements for understanding and modeling hydrologic fluxes as well, including almost every facet of the hydrologic cycle, though we focus here on those primarily within the MENA region. Several studies integrated satellite-based hydrologic estimates into hydrologic models to quantify water resources $([4,10,15,16,19,21-24]$ among others). The use of GRACE data for understanding water resources [8,25-28] and within hydrologic models has also been on the rise [29-31]. TRMM satellite products are widely being used in many parts of the world and particularly in the Middle East and North Africa (MENA) region [4,32-36].

The MENA region is similar to other dryland environments where the combination of natural and anthropogenic impacts is depleting current water resources beyond current and projected needs [26]. For example, the unconfined Plio-Quaternary aquifer in the Souss-Massa basin of southwestern Morocco, which consists mostly of sand and gravel, is being harvested by more than 20,000 wells at a rate of $650 \mathrm{Mm}^{3} / \mathrm{yr}$., exceeding the rate of recharge by $260 \mathrm{Mm}^{3} /$ year [37]. Intense development over the past 50 years has exposed the aquifer to serious water table drawdown (0.5-2.5 m/yr.), land subsidence, salinization, and other deterioration of water quality across the watershed [38].

Understanding the availability and flux of water under changing climatic and anthropogenic forcings is critical in Morocco and worldwide, given rising populations and the unsustainable use of finite water resources. A clear and quantifiable approach for assessing current and future water resources is needed for most of the world. Unfortunately, to date, the monitoring systems needed to estimate precipitation, runoff, and recharge are absent on a regional scale for the majority of the Earth's surface [3,39-42]. This situation makes it difficult to characterize and to monitor the key reservoirs of the water cycle and fluxes to those reservoirs, such as groundwater recharge. Fortunately, recent advances and applications encompassing multi-disciplinary approaches hold the promise to address these inadequacies. Given recent trends, it's becoming increasingly important to have a more complete understanding of the interactions and feedback between climate change and water resources. These interactions are generally understood qualitatively; however, quantitative consequences are speculative, estimated, or unknown. Tackling these questions is exacerbated by the lack of data on proper scales.

This paper demonstrates an integrated approach which combines remote sensing, hydrologic models, statistical analyses, and climate change projections to capture the recent climatic changes in precipitation and total water storage, assess current and future water resources, examine the interactions between climate and water resources (surface and groundwater) in a semi-arid environment, and provide a potential integrated methodology to assess water-scarce and data-scarce watersheds. 
Regional techniques (e.g., remote sensing, land surface models) were carried out in Northern Morocco, and watershed-scale investigations (e.g., watershed modeling, climate projections) were performed in the Oum Er Rbia and Souss Basins of Morocco given the diverse climatic extremes, hydrologic variability, and lack of in-situ observations (Figure 1). As is the case in many developing countries, these basins lack adequate spatially distributed ground-based systems for periodically monitoring and assessing the water situation. Thus, this study also serves as a potential roadmap for better understanding water resource impacts in ungauged basins elsewhere. The study area is typical of many basins in the Mediterranean and Middle East and North Africa (MENA), and is potentially replicable elsewhere.

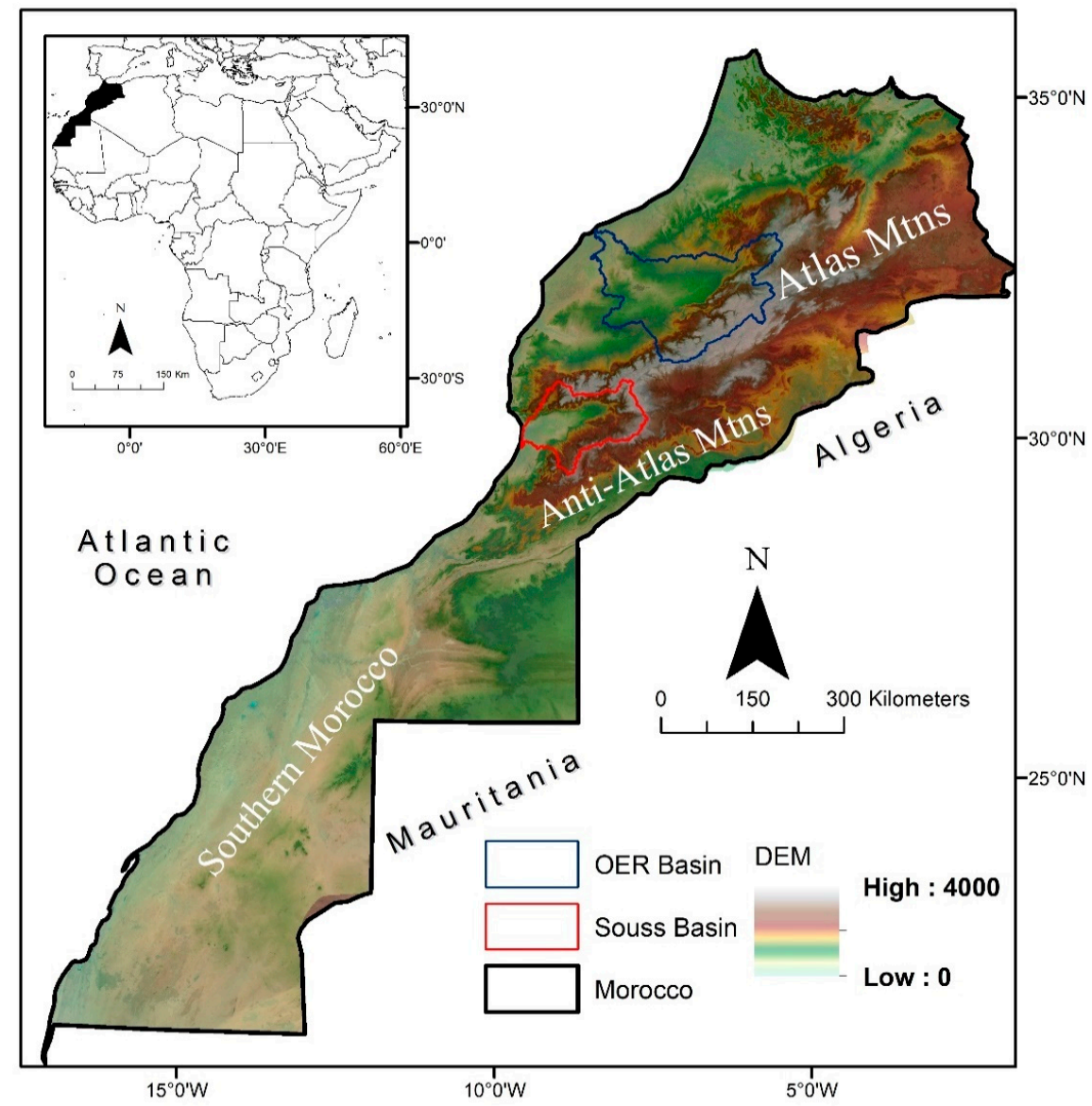

Figure 1. Digital Elevation Model of Morocco with the Souss (outlined in red) and Oum Er Rbia (outlined in blue) Basins highlighted.

\section{Site Description}

The current climate system in Morocco is affected by the Atlantic Ocean in the West, the dry currents from the South and the East and the Mediterranean weather patterns from the North [9]. In addition, Morocco encompasses two large mountain chains (e.g., Rif and Atlas) inducing strong anisotropy of precipitation [43]. This dynamic system is located in a highly sensitive region to climatic changes, where extreme events (e.g., droughts and floods) have been observed with increasing frequencies [44]. Regional studies have shown that precipitation in North Africa in general is projected to decrease by up to $20 \%$ and temperature to increase up to $3{ }^{\circ} \mathrm{C}$ by 2050 , with a pronounced trend in Morocco in particular [45]. These regional and local changes are affecting both the quality and sustainability of water resources, particularly groundwater, for the country. Morocco's economy is heavily dependent on agriculture, the country's largest employer which has been estimated to use 
$87 \%$ of the country's water withdrawals [45]. The combination of decreasing water supply and strong demand intensifies the stressed situation in Morocco.

The Souss Basin is characterized by an arid climate, dense population, limited water resources [38,46,47], and extensive groundwater abstraction [48]. Souss Basin is located in the Southern part of Morocco and receives approximately $250 \mathrm{~mm}$ of precipitation per year. The total water extraction in the basin is estimated at 650 million cubic meters per year. Groundwater extraction rate in the basin exceed the recharge by 260 million cubic meters per year, leading to water level declines ranging from 0.5 to $2.5 \mathrm{~m} /$ year during the past three decades [38].

The Oum Er Rbia basin area is about $38,000 \mathrm{~km}^{2}$ and encompasses the longest river of Morocco (i.e., the Oum Er Rbia River). The watershed originates in the High Atlas where maximum elevations reach $3986 \mathrm{~m}$ a.s.l. and discharges in the Atlantic Ocean where elevation reaches $0 \mathrm{~m}$ a.s.l in the coastal Meseta plain. The climate of the Oum Er Rbia watershed ranges from semi-arid in the plain to sub-humid at the Atlas Mountains, with a dominance in both cases of two distinct wet and dry seasons [49]. The basin is considered one of the main agricultural areas in Morocco, using most of its water resources in irrigation producing maize, wheat, olives, and sugar beets, among other crops [50].

Morocco's economy is heavily dependent on agriculture, the country's largest employer which has been estimated to use $87 \%$ of the country's water withdrawals [45]. The combination of decreasing water supply and strong demand intensifies the stressed situation in Morocco. For both Souss and Oum Er Rbia watersheds, agriculture is the largest water consumer and withdrawals for irrigation peak in the dry period of the year putting more pressure on groundwater resources [50]. In addition, both basins suffer from deteriorating water quality by saltwater intrusion, overuse of fertilizers and pesticides, and untreated wastewater discharges.

\section{Methodology, Results, and Discussion}

A three-fold approach was used to offset the lack of field data, yet still examine the interactions and trends in climate change and total water resources in a typical managed, arid environment. First, regional and watershed-scale variations in precipitation, total water storage change, and groundwater level changes were quantified using TMPA 3B43v7, GRACE RL05, and Global Land Data Assimilation System (GLDAS) datasets. Second, remote-sensing-based rainfall-runoff models were constructed to assess the current water resources budget. Third, projected climate change impacts were estimated from a 40-General Circulation Model (GCM) ensemble using IPCC AR5 data and combined with hydrologic models to estimate the potential climate change impact. Figure 2 shows the objectives, data inputs/outputs, and how the results link together to better understand water resources in Morocco as well as the connection between groundwater and climate change.

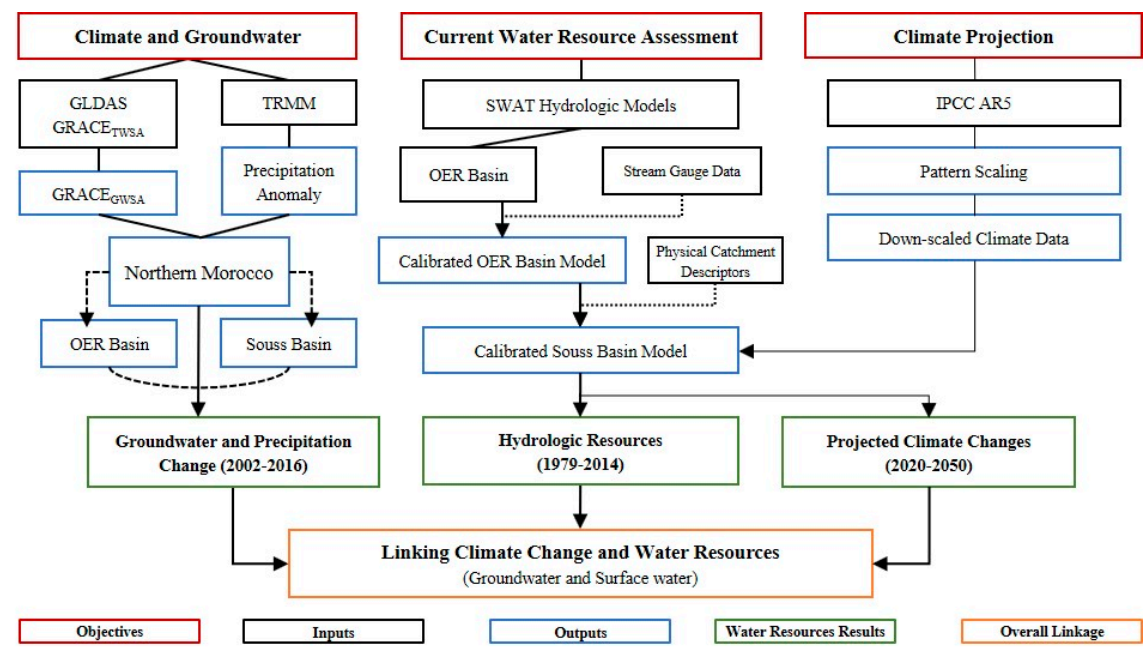

Figure 2. Overall objectives and methodology workflow. 


\subsection{Multi-scale Precipitation and Water Storage Variations}

Temporal geospatial data, terrestrial water storage (TWS) anomaly from GRACE, land surface model outputs from GLDAS and precipitation from TRMM, were processed and analyzed to assess the spatial and temporal variations in water resources in the study area and examine the influence of climatic changes on total water resources (e.g., surface and groundwater). Temporal variations in total water storage, groundwater change, and precipitation were statistically analyzed to discern the link between climate and anthropogenic impacts with groundwater.

\subsubsection{Datasets and Processing}

The application of satellite precipitation data (e.g., TRMM, GPM,) in hydrologic research has been on the rise due in large part to data paucity or lack of adequate in-situ rain gauge measurements for the majority of the Earth's surface and improving algorithms (e.g., TMPA V5-V7) [9]. One of the most widely used satellite-based precipitation products is the TRMM Multi-Satellite Precipitation Analysis (TMPA) [51]. Monthly TMPA precipitation (3B43V7) data were acquired from NASA Mirador for the period 2002-2016. Monthly time series and long-term averages were computed and compared with the GRACE data over the study area.

NASA GRACE data combined with the GLDAS outputs [52] was used to quantify changes in the total water storage and groundwater storage components. The GRACE satellite mission provides large scale (e.g., $>30,000 \mathrm{~km}^{2}$ ) estimates of aggregate changes in total terrestrial water storage including change in snow storage, surface water storage, storage in the unsaturated zone, and storage in the saturated zone. The GRACE mission consists of twin satellites flying in tandem orbit at $\sim 500 \mathrm{~km}$ altitude with a long-track separation distance of $\sim 220 \mathrm{~km}$ and inclination of $89.50^{\circ}$ [53]. The onboard microwave instrument measures the variation in speed and distance between the twin satellites due to perturbation of the orbital motion of the satellites caused by the change in the gravitational field related to mass change. The GRACE signal contains several temporal signals; however, the hydrology signal dominates on the monthly scale making it useful for the hydrologic community. Therefore, gravity anomaly measurement from GRACE is processed and converted into a terrestrial water storage anomaly (TWSa) product. GRACE data has successfully been used in numerous groundwater applications $([19,21,26,54-56]$ among others), and in evaluating climatic changes on groundwater reserves (e.g., [17,57]).

The GRACE data (Level 3, RL-05 gridded $\left[1^{0} \times 1^{0}\right]$ ) was obtained from the CSR, JPL, and GFZ processing centers [58,59]. An ensemble mean of the three GRACE solutions were used to help suppress the errors associated with each processing center. GRACE land data are available at http://grace.jpl.nasa.gov, supported by the NASA MEaSUREs Program. GRACE TWSa data (2002-2016) was multiplied by the scale factors, and leakage and measurement errors on the scaled GRACE data for the study area were calculated and included in the analysis [58,59] (Figure 3).

Hydrological data is essential for isolating groundwater storage change anomaly (GWSa) from GRACE-based TWS anomaly (TWSa). GRACE-derived TWSa represents the combined effects of surface water and groundwater storage changes. Separately estimating groundwater storage changes requires isolating it by quantifying surface water storage anomaly variables (e.g., soil moisture, snow water equivalent, and canopy storage anomalies) and removing them from GRACE's TWS observations [60-62] (Equation (1)). Due to the lack of ground-based measurements in our area of study, model estimates from GLDAS were used to account for surface water storage components [52]. GLDAS is a system that generates land surface states and fluxes by parameterizing satellite and ground-based observational data into advanced land surface models [52]. For this study, we used the monthly, 1 × 1-degree, version-1 land surface parameters simulated by NOAH 2.7.1 in GLDAS [63]. GWSa was calculated using the following mass balance equation:

$$
\mathrm{GWSa}=\mathrm{TWSa}-\mathrm{SMa}-\mathrm{SWEa}-\mathrm{CWa}
$$


where SMa is soil moisture anomaly, SWEa is change in snow water equivalent, and CWa is change in canopy water storage. All units are expressed as a vertical water column in $\mathrm{cm}$. A linear model was fit to the data to test for the presence of any statistically significant trends (using a significance level, $\alpha=0.05)$ in the GWSa and TWSa.
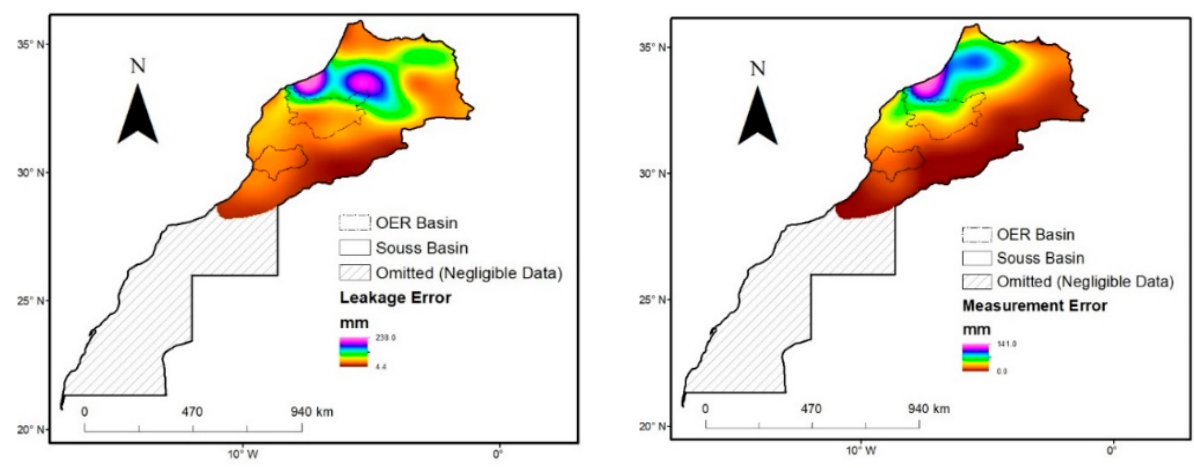

(A)
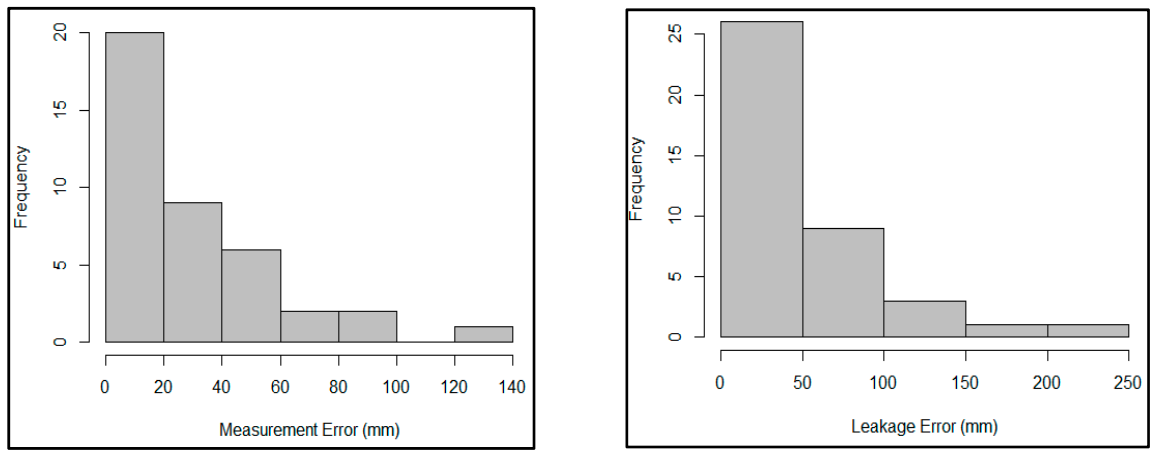

(B)

Figure 3. (A) Measurement and leakage errors for GRACE; (B) Histogram error distribution for measurement and leakage errors within Morocco.

\subsubsection{Error Analysis}

GRACE is often used on larger scales than those used in this study due to possible measurement or leakage errors. Therefore, measurement and leakage errors were calculated on the scaled GRACE data (Figure 3) [58,59]. Inspection of Figure 3 shows that the higher errors are located outside of the studied watersheds, and most of the errors within Northern Morocco are less than 20mm. Satellite-based precipitation retrievals are also known to have errors due to terrain, precipitation type, and climate (TRMM errors, particularly over mountainous regions [64]. Previous research by the authors has shown that TRMM TMPA results compare well with in-situ gauges in Our Er Rbia basin (Pearson Correlation Coefficients: 0.50-0.93) [9].

\subsubsection{Water Flux Results}

Figure 4 displays the spatial variation of TWSa change in northern Morocco. Results show that northwestern Morocco is gaining water storage over the study period, while eastern and southern Morocco, including the Souss Basin (black polygon in Figure 4A), has stable total terrestrial water storage (Souss Basin: $\sim 0.9 \mathrm{~cm} / \mathrm{yr}$.). A negative GWSa exists for Morocco $(-0.85 \mathrm{~cm} / \mathrm{yr}$.), and the Souss Basin $(-11.8 \mathrm{~cm} / \mathrm{yr}$.), whereas a positive GWSa $(2.77 \mathrm{~cm} / \mathrm{yr}$.) is exhibited in the OER Basin. The Souss basin receives less precipitation compared to other parts of the country, ranging between 50 to $250 \mathrm{~mm}$ per year, and an annual average of $\sim 250 \mathrm{~mm} / \mathrm{yr}$. However, precipitation is higher in the northern portion of the Souss Basin (Figure 4B). Oum Er Rbia receives more precipitation given their proximity to the mountains (Figures 3 and 4B). Figure 5 examines the temporal trends in TWSa, GWSa, and precipitation in Morocco (Figure 5A), Oum Er Rbia Basin (Figure 5B), and Souss Basin (Figure 5C). Precipitation in 
Morocco displayed seasonal variations; however, no statistically significant trend exists in the country (slope $=0.00116, p$-value $=0.969)$ as a whole, in the Souss Basin (slope $=0.06042, p$-value $=0.26153)$, or the Oum Er Rbia Basin (slope $=-0.044$, $p$-value $=0.369$ ) (Table 1). Similarly, the area-averaged TWSa in Morocco has no statistically significant trend (slope $=-0.01271, p$-value $=0.778$ ), though it does have a decreasing trend in GWS anomaly (slope $=-0.3998, p$-value $=0.00238$ ). This implies that the climate has remained relatively consistent during the past fifteen years, as has the total water storage; however, anthropogenic impacts have increased, as evidenced by the decreasing trends in GWS anomaly in Morocco. These impacts are amplified in the Souss Basin. Precipitation has slightly increased, though not statistically significant since 2002 in the Souss Basin, whereas TWS and GWS anomalies exhibit statistically significant negative trends (Table 1). This is primarily attributed to over-pumping in the region. Whereas, the OER Basin has an increase in TWSa and GWSa though neither are statistically significant (Table 1 ).

Table 1. Statistical analysis of the trends in precipitation, TWS anomaly, and GWS anomaly for Morocco and the Souss Basin. TWS anomaly in Souss Basin and GWS anomaly in both the Souss Basin and Morocco shows statistically significant decreasing trends ( $p$-value $<0.05$ ).

\begin{tabular}{cccc}
\hline & Precipitation & TWS Anomaly & GWS Anomaly \\
\hline \multicolumn{5}{c}{ Morocco } \\
\hline Slope & 0.00116 & -0.0127 & -0.3998 \\
t-value & 0.039 & -0.282 & -3.117 \\
$p$-value & $0.969^{*}$ & $0.778^{*}$ & $2.38 \times 10^{-3}$ \\
\hline \multicolumn{5}{c}{ Souss Basin } \\
\hline Slope & 0.06042 & -0.068 & -0.4085 \\
t-value & 1.127 & -2.42 & -5.269 \\
$p$-value & $0.26153^{*}$ & $0.0167^{*}$ & $7.91 \times 10^{-7}$ \\
\hline \multicolumn{5}{c}{ OER Basin } \\
\hline Slope & -0.044 & 0.11317 & 0.1 \\
t-value & -0.9 & 1.233 & 1.77 \\
$p$-value & $0.369^{*}$ & $0.219^{*}$ & $0.0787^{*}$ \\
\hline
\end{tabular}

(* indicates the result is not statistically significant).

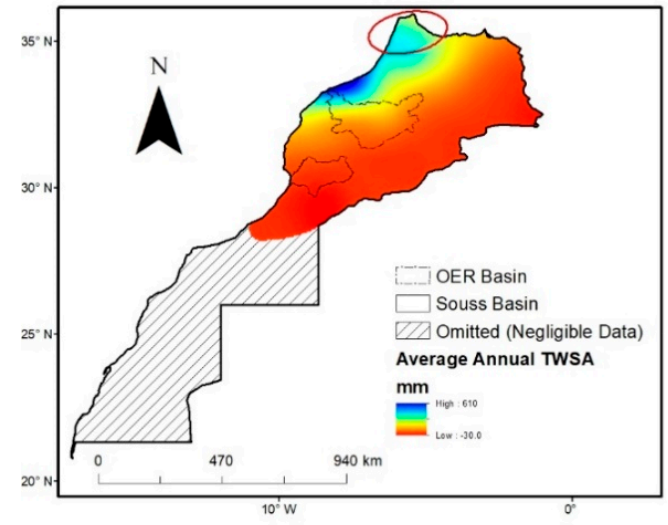

(A)

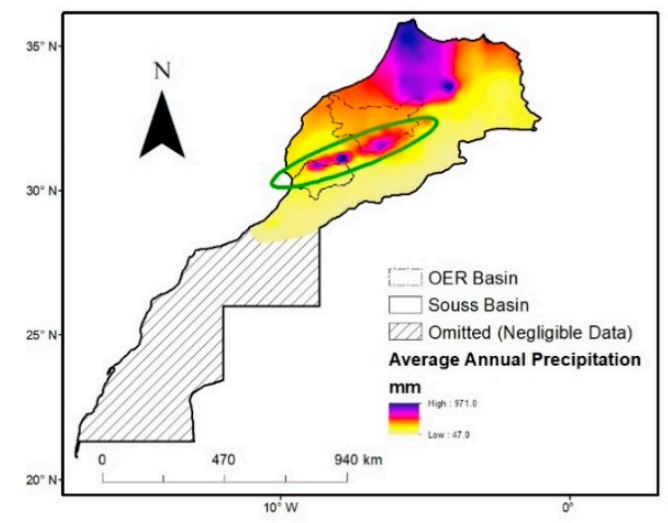

(B)

Figure 4. (A) Average annual GRACE-derived TWS anomaly (2002-2016); (B) Average annual TMPA-derived precipitation (2002-2016). Also shown are areas of high correlation between TWS anomaly and precipitation (red oval) and high precipitation yet low TWS anomaly (green oval). 

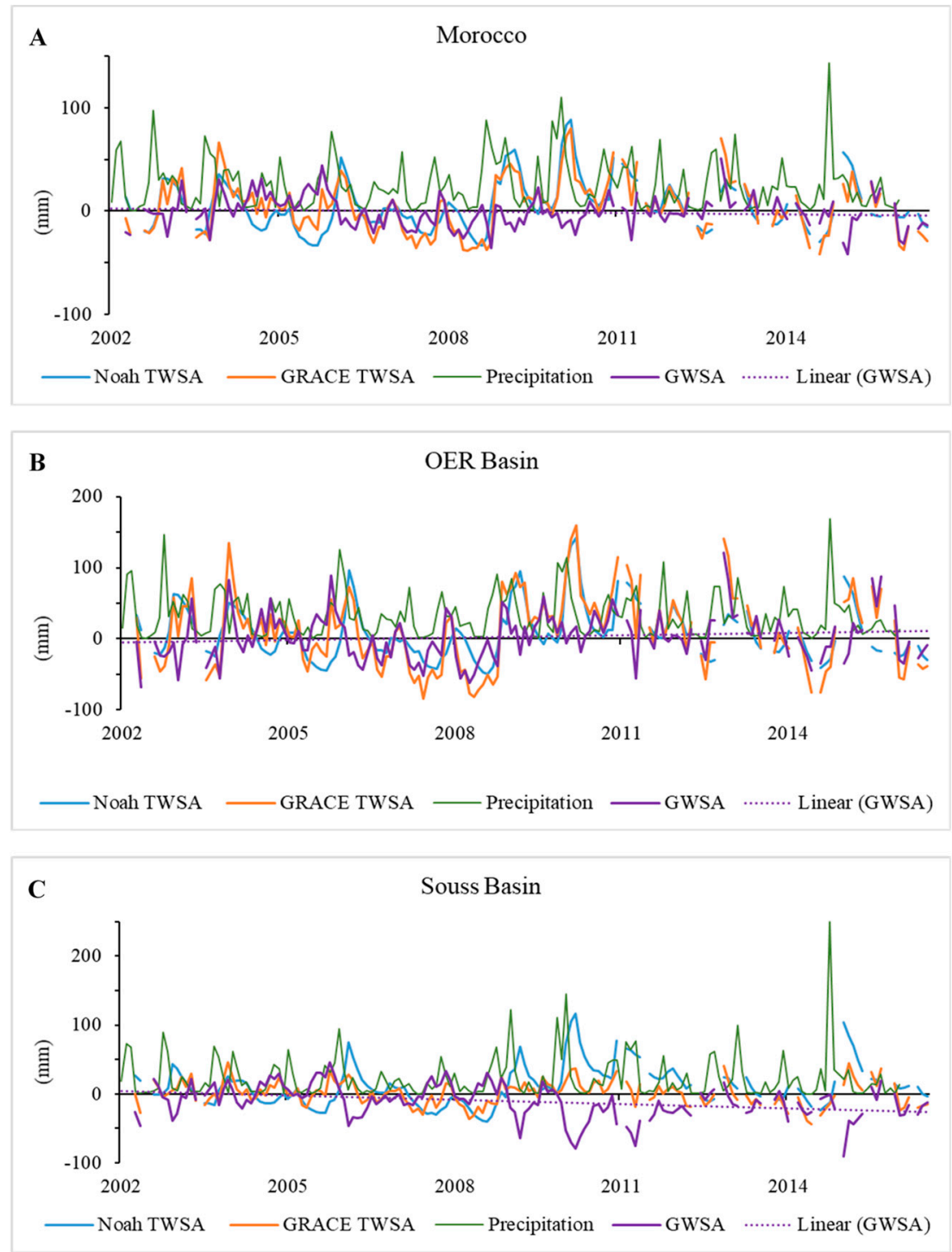

Figure 5. (A) Monthly TWS anomaly (orange), GWS anomaly (purple), and precipitation (green) in Morocco; (B) Monthly TWS anomaly (orange), GWS anomaly (purple), and precipitation (green) in Oum Er Rbia Basin; (C) Monthly TWS anomaly (orange), GWS anomaly (purple), and precipitation (green) in Souss Basin.

\subsection{A Remote Sensing-Based Rainfall-Runoff Model}

\subsubsection{Overview and Model Construction}

A satellite-based hydrologic models for the Oum Er Rbia and Souss Basin was constructed using the Soil and Water Assessment Tool (SWAT) model to estimate current water resources (surface and groundwater) in the Moroccan Basins (Figure 1). The SWAT model was selected for its ability to provide continuous simulation of multiple hydrologic processes (e.g., overland and channel flow, transmission losses, evapotranspiration, potential recharge) over extended periods of time $[65,66]$ and its integration of diverse GIS and weather data sources including the use of public domain global datasets. SWAT has been extensively used and validated at various spatial and temporal scales in arid and semi-arid regions worldwide ([4,16,67-70] among others).

SWAT is a continuous, semi-distributed, physically based model designed to simulate water, nutrient and pesticide transport at a catchment scale on a daily time step [65]. SWAT represents various hydrologic processes (interception, evapotranspiration, surface runoff, soil percolation, lateral 
flow, groundwater flow and river routing processes) within a catchment. The soil water balance is the primary process in each hydrologic response unit and is represented below after Arnold et al. (1998) [65] (Equation (2)):

$$
S W_{t}=S W+\sum_{i=1}^{t}\left(R_{i}-Q_{i}-E T_{i}-P_{i}-Q R_{i}\right)
$$

where $S W$ is the soil water content, $i$ is the time in days from the simulation period $t, R$ is daily precipitation, $Q$ is runoff, ET is evapotranspiration, $P$ is percolation, and $Q R$ is return flow. For a more detailed description of SWAT, see Neitsch et al. (2011) [71].

\subsubsection{SWAT Model Inputs}

SWAT requires several basin-specific datasets, including the primary inputs for topography, landuse, soil, and climate. SWAT can simulate various physical processes found within the basin, including changes in climate, hydrologic processes, land and water use, water quality, and water quantity assessments [68]. SWAT spatial data inputs used in the hydrologic models (Figures 6 and 7) include: (1) Topographical terrain data obtained from ASTER Digital Elevation Model (ASTER-GDEM V2) at 30m resolution (database: http://reverb.echo.nasa.gov) (Figures 6A and 7A); (2) Land cover and landuse data obtained from USGS Global Land Cover Characterization database (http://edc2. usgs.gov/glcc/glcc.php) (Figures 6B and 7B); (3) Soil data obtained from Harmonized World Soil Database v1.2 through the Food and Agriculture Organization of the United Nations (FAO) Soils Portal [72] (http://www.fao.org) (Figures 6D and 7D); and (4) Climate data obtained from The National Centers for Environmental Prediction (NCEP) Climate Forecast System Reanalysis (CFSR) (http://globalweather.tamu.edu) compiled over the 36-year period of 1979-2014. The CFSR weather data uses conventional meteorological gauge observations and satellite irradiances as well as atmospheric, oceanic, and surface-modeling components at $\sim 38 \mathrm{~km}$ resolution [73]. Weather data collected for the Souss Basin comprised 55 weather stations with data compiled from 1979 to mid-2014. Climate data is provided on a daily time-step and includes precipitation $(\mathrm{mm})$, temperature $\left({ }^{\circ} \mathrm{C}\right)$, wind speed $(\mathrm{m} / \mathrm{s})$, relative humidity (fraction), and solar radiation $\left(\mathrm{MJ} / \mathrm{m}^{2}\right)$. The goal of the model was to accurately represent and simulate the hydrologic processes based on the physical-based attributes of the basin.

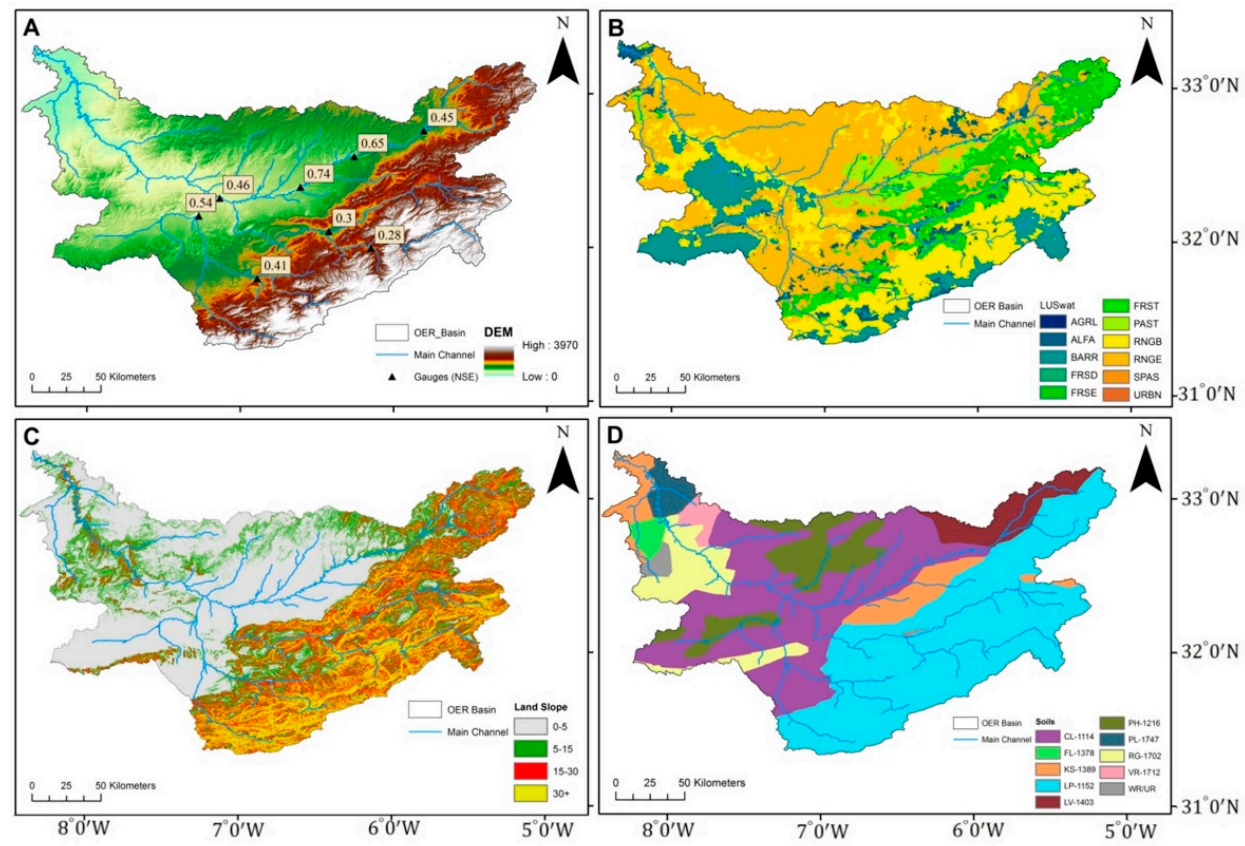

Figure 6. OER Model input: (A) Digital Elevation Model; (B) landuse; (C) percent slope; and (D) soils. 

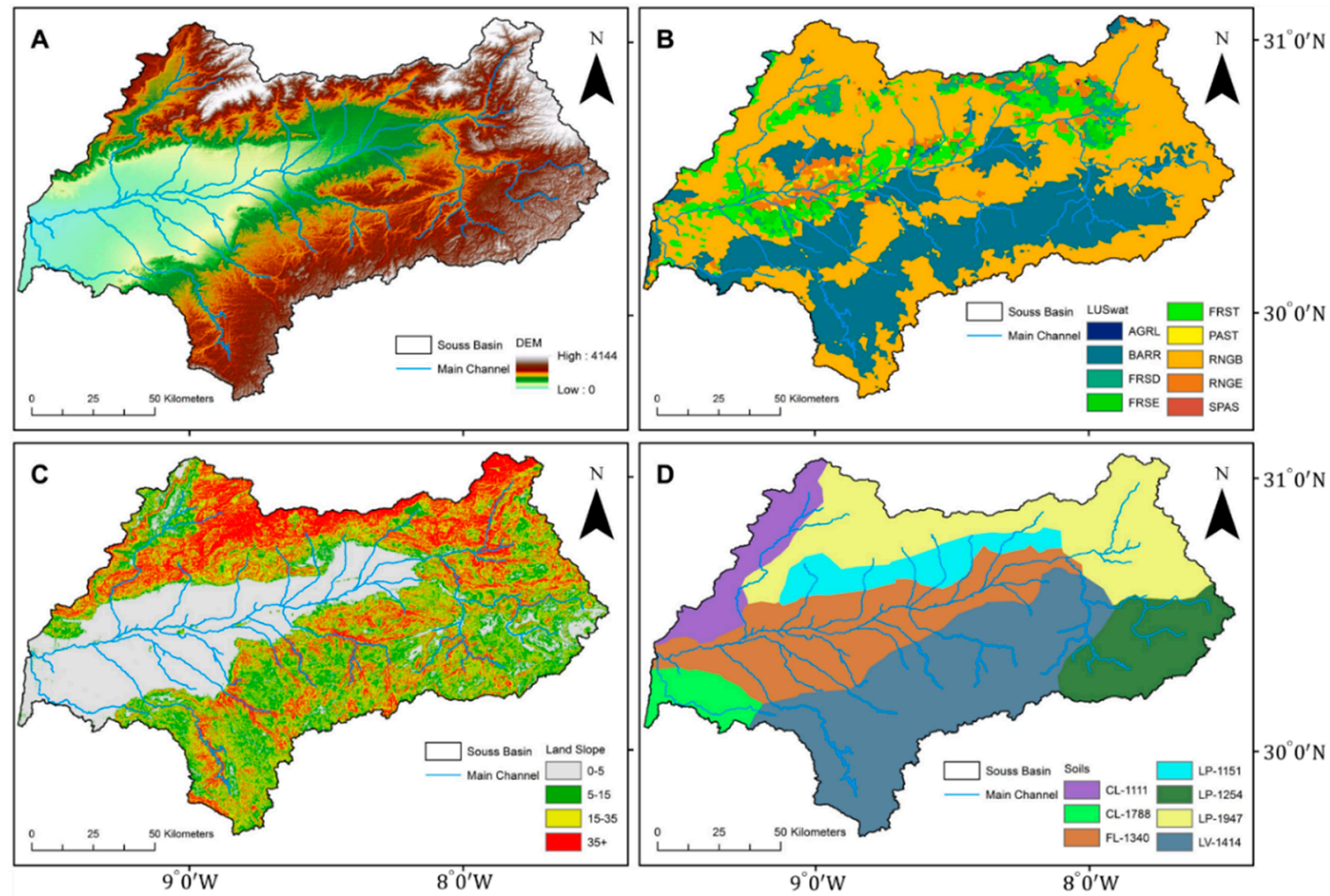

Figure 7. Souss Model input: (A) Digital Elevation Model; (B) landuse; (C) percent slope; and (D) soils.

\subsubsection{SWAT Model Setup: Oum Er Rbia Basin Model}

The model partitioned the Oum Er Rbia Basin (OER) (37,408 km²) into 105 hydrological response units with simulation run at daily time-step over a 36-year period, including a two-year warm-up period, corresponding to available weather datasets. Nine major soil groups $(37.12 \%$ encompassing two classifications of Lithosols [LP-1152], 29.43\% encompassing two classifications of Calcisols [CL-1114], 8.25\% Luvisols [LV-1403], 7.91\% encompassing two classifications of Phaeozems [PH-1216], 7.02\% encompassing two classifications of Kastanozems [KS-1389], 6.54\% Regosols [RG-1702], 1.96\% Planosols [PL-1747], 1.02\% Vertisols [VR-1712], and 0.75\% Fluvisols [FL-1378]) and seven major land uses groups (40.35\% Range-Grasses [RNGE], 23.02\% Range-Brush [RNGB], 12.67\% Barren [BARR], 6.69\% Forest-Mixed [FRST], 6.28\% Forest-Evergreen [FRSE], 5.64\% Pasture [PAST], 4.66\% Alfalfa [ALFA], and the remaining $0.66 \%$ comprised of-Summer Past [SPAS], Forest-Deciduous [FRSD], Residential [URBN] and Agricultural Land-Generic [AGRL]-classification based from SWAT database) are found in the Oum Er Rbia Basin. Additionally, there are four slope classes (0-5 percent slop: $47.51 \%$, 5-15 percent slope: $21.27 \%, 15-30$ percent slope: $16.01 \%$ and greater than 30 percent slop: $15.21 \%$ (Figure 6A-D).

\subsubsection{SWAT Model Setup: Souss Basin Model}

The model partitioned the Souss Basin $\left(16,980 \mathrm{~km}^{2}\right)$ into 102 hydrological response units with simulation run at daily time-step over a 36-year period, including a two-year warm-up period, corresponding to available weather datasets. Four major soil groups (39.25\% encompassing three classifications of Leptosols [LP-1151, 1254, and 1947], 29.6\% Luvisols [LV-1414], 20.99\% Fluvisols [FL-1340], and 10.17\% including two classifications of Calcisols [CL-1111 and 1788]) and nine major land uses groups (52.34\% Range Brush [RNGB], 29.74\% Barren [BARR], 9.67\% Mixed Forest [FRST], $4.28 \%$ Range Grasses [RNGE], 2.86\% Deciduous Forest [FRSD], and the remaining $1.11 \%$ comprised of Forest-Evergreen [FRSE], Pasture [PAST], Summer Pasture [SPAS], and Agricultural Land-Generic [AGRL]-classification based from SWAT database) are found in the Souss Basin. Additionally, there are 
four slope classes ( $0-5$ percent slop: $31.33 \%$, 5-15 percent slope: $22.57 \%$, $15-35$ percent slope: $28.40 \%$ and greater than 35 percent slope: $17.70 \%$ ) (Figure 7A-D).

Estimated initial losses for each of the HRUs were estimated using the US Department of Agriculture's Soil Conservation Service method [74,75], a method successfully applied to ephemeral watersheds in southwestern United States and in North and East Africa $[4,16,76,77]$.

\subsubsection{Model Calibration}

A two-step approach was implemented to construct and calibrate the hydrologic models: (1) a hydrologic model was created and calibrated for a gauged basin (Oum Er Rbia Basin); (2) calibrated model parameters from OER were transferred to Souss Basin. Following this approach, the calibrated Souss model was used to estimate the current and future available water resources. Souss was selected for more detailed study given the recent groundwater storage changes. Regionalization techniques where calibrated catchment-specific parameters were successfully transferred to similar ungauged proximal catchments can be found throughout the literature (e.g., $[4,15,78-80])$. These techniques involve identification of a set of physical catchment descriptors (PCDs: e.g., geography, climate, topography, geology, catchment size) that could be used as indicators to whether catchment-specific parameters could be extrapolated to an ungauged basin (e.g., Gauged: Oum Er Rbia; Ungauged: Souss). Therefore, a SWAT model was set up and calibrated for Oum Er Rbia Basin, an adjacent basin found in Morocco with similar settings as Souss (e.g., soils, slope, climate: see Figures 6 and 7). Both basins extend from the foot of the Atlas Mountain to the coastal plains, with characteristics of mountainous in the upstream to flat land in the downstream side near the coast (Figure 1). Once the hydrologic model of Oum Er Rbia Basin was satisfactorily calibrated, the model parameters were transferred to the uncalibrated Souss Basin given the similarities in climate (OER rainfall: $~ 550 \mathrm{~mm} / \mathrm{yr}$;; Souss rainfall: $\sim 250 \mathrm{~mm} / \mathrm{yr}$.), geology, topography (range: $0-2500 \mathrm{~m}$ ), landuse, soils, stream density, water sources, and physical environment.

The SWAT model for Oum Er Rbia watershed was evaluated through sensitivity analysis and calibration using automatic calibration techniques (e.g., ParaSol) in SWAT-CUP (SWAT Calibration and Uncertainty Procedures [81]. Parameter sensitivity provides insight into the model response to changes in model parameters, which helps to identify sensitive calibration parameters, as well as adjust initial range of values for further model calibration. Model calibration involves establishing a statistical relationship between model parameters and the characteristics of the watershed.

Model evaluation of the Oum Er Rbia Basin was conducted on a monthly time scale for the period of 1979-2007, where the first two years were considered as model initialization. The model was calibrated with six streamflow gauging stations (Chacha N'Amellah-Sour, Dchar El Oued-Oum Er Rbia, Mechra Eddahk-Oum Er Rbia, Ouled Sidi Driss-Oum Er Rbia, Aït Ouchene-El Abid, and Sgatt-Bernat) distributed within the watershed. Three of the stations are located along the main river, Oum Er Rbia River, where the remaining three are located along tributaries. The SUFI2 (Sequential Uncertainty Fitting-2) procedure in SWAT-CUP (SWAT Calibration and Uncertainty Procedures) was used for sensitivity analysis, uncertainty analysis, autocalibration, and validation of the watershed model $[81,82]$. The model performances were statistically evaluated using the Nash-Sutcliffe (NS) efficiency, the coefficient of determination $\left(\mathrm{R}^{2}\right)$ and percent bias (PBIAS). Model calibration results are generally considered "satisfactory" if the NSE value is greater than 0.36 and "very good" when greater than 0.75 [83-86]. Model calibration results are generally considered "satisfactorily" when monthly-simulated SWAT model water flow at the watershed scale have an NS value $>0.55, R^{2}$ values $>0.7$ and PBIAS $<15 \%$.

\subsubsection{Model Calibration and Results}

Table 2 shows model calibration parameters, sensitivity analysis results, and the initial and simulated values. The $t$-stat in Table 2 provides a measure of the sensitivity of the parameters where the larger absolute value is the more sensitive model parameter. Likewise, the $p$-value determines the 
significance of the sensitivity results. Values closer to zero are considered more statistically significant. The most sensitive parameters were then used in the final calibration simulations. The calibration statistics (Table 2, Figure 8) demonstrate that the model sufficiently matches the observed streamflow in the Oum Er Rbia Basin. The OER model has an average NSE value of 0.65 with a high of 0.74 , and R2 value greater than 0.75 between the simulated and observed flow (Figure 8).

Following the successful calibration of the OER Basin and construction of a SWAT model of the Souss Basin as described previously, the Souss model was run from 1979-2014. Figure 9 displays the seasonal variations and monthly averages in precipitation, runoff, and potential recharge for the simulated period. The average annual precipitation, runoff, and recharge are $214.8 \mathrm{~mm}, 81.9 \mathrm{~mm}$, and $24.89 \mathrm{~mm}$, respectively (Table 3). Simulated (1979-2014) potential renewable groundwater resources obtained from SWAT are $\sim 4.3 \times 10^{8} \mathrm{~m}^{3} / \mathrm{yr}$.

Table 2. SWAT model variables, initial and calibrated values, sensitivity results, and best model variables [84-86].

\begin{tabular}{cccccc}
\hline \multirow{2}{*}{ Variable Name } & \multicolumn{2}{c}{ Initial } & \multicolumn{2}{c}{ Sensitivity } & \multirow{2}{*}{ Best Variable Values } \\
\cline { 2 - 5 } & Minimum & Maximum & t-Stat & $p$-Value & \\
\hline v__GW_DELAY.gw & 30 & 450 & 38.91299 & 0 & 43.04 \\
r_SOL_K(1).sol & -0.8 & 0.8 & -35.9575 & 0 & 0.64 \\
v__CHRG_DP.gw & 0 & 1 & 29.64671 & 0 & 0.00 \\
v__LPHA_BNK.rte & 0 & 1 & -28.3595 & 0 & 0.39 \\
r_CN2.mgt & -0.2 & 0.2 & 14.59158 & 0 & -0.19 \\
v_GWQMN.gw & 0 & 2 & 13.18215 & 0 & 0.01 \\
v_CH_N2.rte & 0 & 0.3 & 9.827674 & $1.17 \times 10^{-22}$ & 0.02 \\
v_CH_K2.rte & 5 & 130 & 9.065615 & $1.56 \times 10^{-19}$ & 7.89 \\
v_CH_K1.sub & 0 & 300 & 8.907304 & $6.48 \times 10^{-19}$ & 37.99 \\
v_ALPHA_BF.gw & 0 & 1 & -8.80199 & $1.65 \times 10^{-18}$ & 0.78 \\
v_CH_N1.sub & 0.01 & 30 & -3.56627 & 0.000364 & 27.93 \\
v_OV_N.hru & 0.01 & 30 & 3.392818 & 0.000695 & 19.13 \\
r_SOL_AWC(1).sol & -0.2 & 0.4 & -1.837 & 0.066249 & -0.19 \\
v_ESCO.hru & 0.8 & 1 & 1.707687 & 0.087736 & 0.86 \\
v_EPCO.hru & 0 & 1 & 1.603297 & 0.108911 & 0.00 \\
v_GW_REVAP.gw & 0 & 0.2 & 1.155803 & 0.247799 & 0.12 \\
v_SFTMP.bsn & -5 & 5 & -0.61932 & 0.535726 & 3.97 \\
v_GW_SPYLD.gw & 0 & 0.4 & -0.57895 & 0.562638 & 0.26 \\
v__REVAPMN.gw & 0 & 500 & 0.550393 & 0.582066 & 0.08 \\
\hline
\end{tabular}

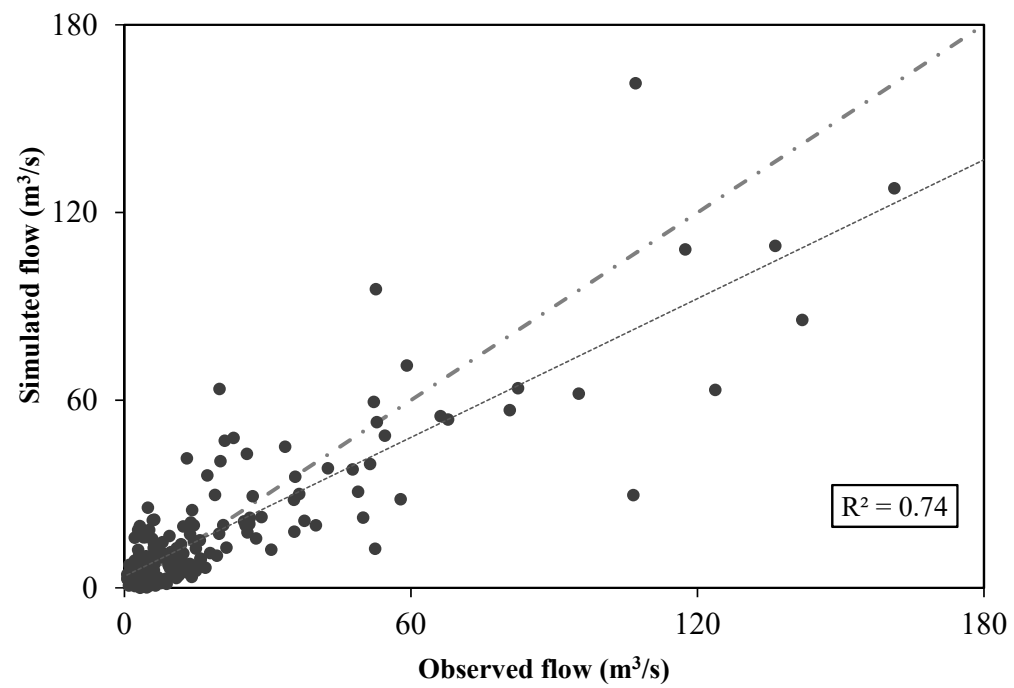

Figure 8. Simulated vs. observed flow in the Oum Er Rbia River at the Mechra Eddahk station. 


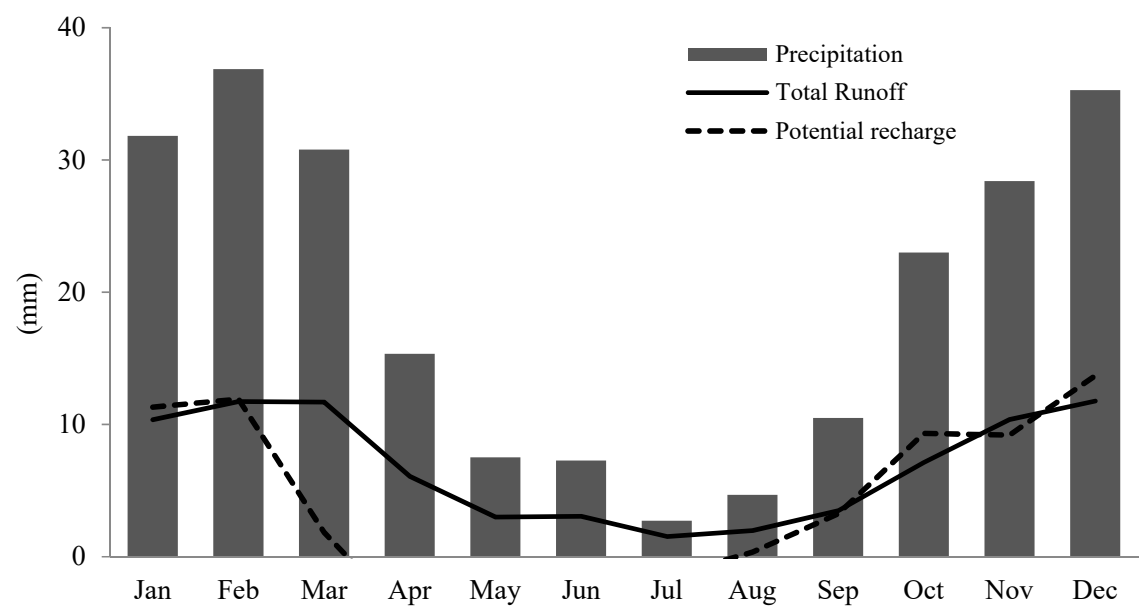

Figure 9. Monthly average (1979-2014) runoff at the outlet (solid line), potential recharge (dashed line), and precipitation (bars) in Souss Basin.

Table 3. Predicted hydrologic parameters due to global climate change using data based on AR5 report of different Representative Concentration Pathways (RCPs), the values in parentheses are percentage changes from the baseline values. SWAT model outputs.

\begin{tabular}{|c|c|c|c|c|c|c|}
\hline \multicolumn{2}{|c|}{ Hydrologic Parameters } & \multirow{2}{*}{$\frac{\mathrm{RCP} 2.6}{-}$} & \multirow{2}{*}{$\begin{array}{c}\text { RCP4.5 } \\
-\end{array}$} & \multirow{2}{*}{$\begin{array}{c}\text { RCP6.0 } \\
-\end{array}$} & \multirow{2}{*}{$\frac{\text { RCP8.5 }}{-}$} & \multirow{2}{*}{$\begin{array}{c}\text { Average } \\
214.8\end{array}$} \\
\hline & Precipitation $(\mathrm{mm})$ & & & & & \\
\hline Baseline & Runoff (mm) & - & - & - & - & 81.89 \\
\hline & Recharge (mm) & 一 & 一 & - & 一 & 24.89 \\
\hline \multirow{4}{*}{2020} & Precipitation (mm) & $204.0(-5.0)$ & $203.8(-5.1)$ & $204.6(-4.7)$ & $203(-5.5)$ & $203.9(-5.1)$ \\
\hline & $\Delta$ Temperature $\left({ }^{\circ} \mathrm{C}\right)$ & 0.56 & 0.56 & 0.52 & 0.61 & 0.6 \\
\hline & Runoff (mm) & $76.4(-6.7)$ & $76.3(-6.8)$ & $76.7(-6.3)$ & $75.9(-7.3)$ & $76.3(-6.8)$ \\
\hline & Recharge (mm) & $22.7(-8.7)$ & $22.7(-8.8)$ & $22.9(-8.2)$ & $22.5(-9.5)$ & $22.7(-8.8)$ \\
\hline \multirow{4}{*}{2025} & Precipitation (mm) & $202.5(-5.7)$ & $201.7(-6.1)$ & $202.8(-5.6)$ & $200.1(-6.8)$ & $201.8(-6.1)$ \\
\hline & $\Delta$ Temperature $\left({ }^{\circ} \mathrm{C}\right)$ & 0.63 & 0.67 & 0.62 & 0.75 & 0.7 \\
\hline & Runoff (mm) & $75.7(-7.6)$ & $75.3(-8.1)$ & $75.8(-7.4)$ & $74.5(-9.0)$ & $75.3(-8.1)$ \\
\hline & Recharge (mm) & $22.4(-9.8)$ & $22.3(-10.5)$ & $22.5(-9.7)$ & $21.9(-11.7)$ & $22.3(-10.4)$ \\
\hline \multirow{4}{*}{2030} & Precipitation (mm) & $201.2(-6.3)$ & $199.5(-7.1)$ & $200.9(-6.5)$ & $197.1(-8.2)$ & $199.7(-7.0)$ \\
\hline & $\Delta$ Temperature $\left({ }^{\circ} \mathrm{C}\right)$ & 0.70 & 0.78 & 0.71 & 0.91 & 0.8 \\
\hline & Runoff (mm) & $75.0(-8.4)$ & $74.2(-9.4)$ & $74.9(-8.6)$ & $73.0(-10.9)$ & $74.3(-9.3)$ \\
\hline & Recharge (mm) & $22.2(-10.8)$ & $21.9(-12.1)$ & $22.1(-11.1)$ & $21.4(-14.0)$ & $21.9(-12.0)$ \\
\hline \multirow{4}{*}{2035} & Precipitation (mm) & $200.2(-6.8)$ & $197.5(-8.1)$ & $199.1(-7.3)$ & $193.9(-9.7)$ & $197.7(-8.0)$ \\
\hline & $\Delta$ Temperature $\left({ }^{\circ} \mathrm{C}\right)$ & 0.75 & 0.89 & 0.81 & 1.08 & 0.9 \\
\hline & Runoff (mm) & $74.5(-9.0)$ & $73.2(-10.6)$ & $74.0(-9.7)$ & $71.4(-12.8)$ & $73.3(-10.5)$ \\
\hline & Recharge (mm) & $22.0(-11.7)$ & $21.5(-13.7)$ & $21.8(-12.5)$ & $20.8(-16.4)$ & $21.5(-13.5)$ \\
\hline \multirow{4}{*}{2040} & Precipitation (mm) & $199.3(-7.2)$ & $195.5(-9.0)$ & $197.3(-8.1)$ & $190.5(-11.3)$ & $195.7(-8.9)$ \\
\hline & $\Delta$ Temperature $\left({ }^{\circ} \mathrm{C}\right)$ & 0.79 & 0.99 & 0.90 & 1.25 & 1.0 \\
\hline & Runoff (mm) & $74.1(-9.5)$ & $72.2(-11.8)$ & $73.1(-10.7)$ & $69.8(-14.8)$ & 72.3(-11.7) \\
\hline & Recharge (mm) & $21.8(-12.3)$ & $21.1(-15.2)$ & $21.4(-13.9)$ & $20.2(-18.8)$ & $21.1(-15.0)$ \\
\hline \multirow{4}{*}{2045} & Precipitation (mm) & $198.6(-7.5)$ & $193.6(-9.9)$ & $195.5(-9.0)$ & $186.9(-13.0)$ & $193.7(-9.8)$ \\
\hline & $\Delta$ Temperature $\left({ }^{\circ} \mathrm{C}\right)$ & 0.83 & 1.09 & 0.99 & 1.43 & 1.1 \\
\hline & Runoff (mm) & $73.8(-9.9)$ & $71.3(-13.0)$ & $72.2(-11.8)$ & $68.1(-16.9)$ & $71.3(-12.9)$ \\
\hline & Recharge (mm) & $21.7(-12.8)$ & $20.8(-16.6)$ & $21.1(-15.2)$ & $19.6(-21.3)$ & $20.8(-16.5)$ \\
\hline \multirow{4}{*}{2050} & Precipitation (mm) & $198.1(-7.8)$ & $193.5(-9.9)$ & $193.6(-9.9)$ & $183.2(-14.7)$ & $192.1(-10.6)$ \\
\hline & $\Delta$ Temperature $\left({ }^{\circ} \mathrm{C}\right)$ & 0.86 & 1.18 & 1.09 & 1.62 & 1.2 \\
\hline & Runoff (mm) & $73.5(-10.3)$ & $71.2(-13.0)$ & $71.3(-12.9)$ & $66.3(-19.0)$ & $70.6(-13.8)$ \\
\hline & Recharge (mm) & $21.6(-13.2)$ & $20.7(-16.7)$ & $20.8(-16.6)$ & $19.0(-23.9)$ & $20.5(-17.6)$ \\
\hline
\end{tabular}




\subsection{Climate Change Projections}

\subsubsection{Overview and Methodology}

Given the connection between climate and groundwater resources, climate change scenarios were simulated using the SimCLIM software package to investigate and analyze potential changes in precipitation and temperature in the Souss Basin. SimCLIM simulates, both temporally and spatially, the impacts of climate variability and scenarios of climate change using emission scenario data and general circulation models (GCMs) in an integrated, open-framework, software package [87]. SimCLIM uses data from the Coupled Model Intercomparison Project, Phase 5 (CMIP5), in accordance with the latest Intergovernmental Panel on Climate Change Fifth Assessment Report (AR5; IPCC 2014 [88]) and forty GCMs with varying Representative Concentration Pathways (RCPs) corresponding to different emission scenarios (e.g., RCP 2.6; 4.5; 6.0; and 8.5) [89]. More information on the transition from the Special Report on Emission Scenarios (SRES: A1F1, A1B, A1T, A2, B1, B2) to RCPs, including the representative carbon dioxide emission scenarios can be found in previous literature (e.g., [90-93]). SimCLIM employs the commonly used method of "pattern scaling" to downscale and generate different climate variables for temporal and spatial scales [94-97]. GCMs can be downscaled using statistical or dynamical approaches and have been applied to Morocco (e.g., Med-CORDEX) (e.g., [42]). However, pattern-scaling has its own merits compared with other methods. As recommended by IPCC, a good assessment should include data sources from multiple GCM/RCM and different methods. Use of a single GCM limits the accuracy of climate projections [94,98]. Pattern scaling focuses more on "climate change signals" that are represented by the differences of GCM data between future and baseline periods. These signals are not adjusted too much by pattern scaling and are almost the original changes predicted by GCMs. Thus pattern-scaling is a simple, easy-to-use, and straightforward method to study climate change. However, this may not be the case for many other downscaling methods as they will change the signals more or less. All of these attributes may add uncertainties to the final resultant regional climate change information. More information regarding SimCLIM and use can be found within the literature $[87,99]$.

Previous research was carried out in Morocco and the Souss Basin regarding potential climate change impacts on water resource availability [42,48,100-103]. These studies, though relevant, examined either different processes (e.g., precipitation or temperature only), different time periods (e.g., 1940s-2010), or used different approaches (e.g., statistical analyses). Our approach used more recent data (2002-2016), hydrologic models, satellite-based remote sensing (e.g., TRMM and GRACE), coupled with a larger scale climate projection model. Therefore, our approach used a GCM ensemble represented to a regional scale using pattern scaling.

We simulated changes in precipitation across Morocco every five years through 2050 using an ensemble of forty GCMs with the full range of RCP scenarios (precipitation and temperature values-Table 3) to account for the range of uncertainties involving future greenhouse gas emissions. A baseline of 1961-1990 was selected as recommended by (IPCC 2014) [88]. The IPCC recommends an ensemble approach when using GCM model data to reduce model-specific bias and provide the best representation of projected climate change [104].

\subsubsection{Climate Change Results}

GCM outputs were incorporated into the Souss Basin SWAT model to generate the corresponding change in water resources (surface runoff and groundwater recharge) (Table 3). We chose to focus only on the Souss Basin given the combination of both natural climatic and anthropogenic impacts seen in this basin. Outputs were then analyzed to discern variations in runoff, recharge, and evaporation in relation to average annual precipitation amounts. These results present the predicted climatic changes in hydrologic processes (e.g., surface runoff, potential recharge, and evapotranspiration) for the Souss Basin. The results do not take into account any human disturbances or responses during the predicted period. Results show an overall decrease in projected precipitation, $-5.1 \%$ in 
2020 to $-10.6 \%$ by 2050 , which in turn leads to decreases in the amount of runoff $(2020:-6.8 \%, 2050$ : $-13.8 \%)$ and potential groundwater recharge (2020: $-8.8 \%, 2050:-17.6 \%)$. Interestingly, the impact of climate change is expected to affect the groundwater more than surface water runoff (rate of GW: $-8.8 \%$, rate of SR: $-7.0 \%$ ), though both exceed the rate of decrease in precipitation (rate of P: $-5.4 \%$ ). The latter is expected in areas that receive low precipitation and higher temperatures where the majority is lost to evapotranspiration. The predicted changes in precipitation and temperature and their differential impact on runoff and recharge can be due to a variation in hydraulic heads and a modification of the relationship between surface and groundwater bodies [105]. This modification is more pronounced in arid/semi-arid environments where the baseflow is irregular and sporadic, and any small perturbation in water supply dynamics (i.e., precipitation, evaporation) leads to a more pronounced effect on groundwater. Though the climate change projections can't be directly compared to the GRACE results given the different time periods (e.g., GRACE: 2002-2016; Climate Projections: 2020-2050), the combination of both of them independently places the Souss Basin in a larger temporal framework (2002-2050) with respect to current and projected changes in water resources. For example, recent precipitation from TRMM suggests precipitation has changed very little, while groundwater storage anomalies from GRACE exhibit a negative trend. The climate change projections show that precipitation will most likely begin to decrease and it will impact groundwater recharges rates, thus magnifying the current decreasing groundwater trends.

\section{Summary and Conclusions}

An integrated approach combining satellite remote sensing, hydrologic models, and climate projections was carried out on multiple scales to quantify water storage variations in Morocco, examine the relationship between climate and groundwater systems, identify potential anthropogenic effects, and investigate climate projections in the future. It should be noted that the intention of this study was not to assess potential adaptation strategies, but rather to provide current and project water resource changes and their link within a changing climate. Future research on potential adaptation strategies could be developed using management models (e.g., [106,107]). The major findings from this multi-scalar approach in a representative arid/semi-arid, data scarce environment were grouped into the following categories: (1) Groundwater/precipitation trends and statistics; (2) Spatiotemporal relationships of groundwater/precipitation; (3) Modern water fluxes; and (4) Future climate change impacts.

\subsection{Groundwater/Precipitation Trends and Statistics}

- The climate (e.g., precipitation) has not significantly changed or impacted this area from 2002-2016, as indicated by a relatively flat trend-line in precipitation for Morocco, and the Oum Er Rbia and Souss Basins (Figure 5). Seasonal variations exist in the precipitation along with anomalous wet (e.g., 2009, 2010, and 2015) and dry years (e.g., 2007, 2014) which further complicates the situation.

- GWSa has decreased in both the Souss Basin and the country of Morocco as a whole from 2002-2016. This result is consistent with decreasing groundwater levels in wells. GWSa actually increased in the Oum Er Rbia Basin by almost $3 \mathrm{~cm} / \mathrm{yr}$. This suggests that natural decreases in precipitation are not the major cause of groundwater decline, particularly in the Souss Basin.

- TWSa increased in Morocco overall and both basins. Again, this suggests the sensitivity to anthropogenic impacts is potentially greater than the climate signal.

\subsection{Spatiotemporal Relationships of Groundwater/Precipitation}

- Anomalous areas of precipitation and groundwater don't consistently overlap in space or time. These can be seen in both the spatial patterns and temporal trends. Hot spots, areas that receive higher or lower average precipitation or TWSa/GWSa changes, show areas where climate is linked to groundwater (Figure 4A-red oval), as well as areas where high anomalous TWS changes don't correspond with higher precipitation (Figure 4B-green oval). This can be attributed to the difference in spatial scale of the two datasets and the recharge lag time. Though these trends exist 
spatially, they don't persist consistently through time. Figure 5A highlights the close relationship between precipitation and groundwater, however deviating in certain years (e.g., 2009, 2010). The same can be seen in the Souss Basin, where GWS anomalies were lowest in the wettest years (e.g., 2009, 2010 in Figure 5A,B-black bar).

\subsection{Modern Water Fluxes and Partitioning}

- $\quad$ SWAT model results indicate that the Souss Basin receives an annual average of $4.3 \times 10^{8} \mathrm{~m}^{3}$ ( $\sim 11 \%$ of precipitation) of potential groundwater recharge each year.

- The partitioning of the water in Souss is as follows: precipitation is $214.8 \mathrm{~mm}$, runoff is $81.9 \mathrm{~mm}$, and recharge is $24.89 \mathrm{~mm}$.

\subsection{Future Climate Change Impacts}

- The climate is projected to get dryer and warmer in Northwest Africa. Results show a decrease in precipitation and increase in temperature (Precipitation decrease by 2050: $-10.6 \%$, Temperature increase by $2050:+1.2{ }^{\circ} \mathrm{C}$ ). This is going to place a higher premium on and use of already diminishing groundwater reserves. These results are consistent with previous literature $[108,109]$.

- The magnitude of decreased precipitation $(-10.6 \%)$ is greater than the decrease in surface runoff $(-13.8 \%)$ and groundwater recharge $(-17.6 \%)$. This would result to the annual potential recharge in the Souss Basin being $3.5 \times 10^{8} \mathrm{~m}^{3}$. This reinforces the need for more prudent water storage and groundwater management strategies. Previous studies using other downscaled GCM approaches show smaller decreases in precipitation and consistent increases in temperature [42], However, decreases in surface runoff were found to be higher than reported here (e.g., $-30 \%$ compared to $-15 \%$ ) which can be attributed to the projected changes in precipitation or differences in models.

There are three main conclusions that can be drawn from this research. First, climate change impacts on groundwater are likely to increase in the near future, however anthropogenic impacts are evident and a potentially larger concern. The data shows evidence of this phenomena during wet years with higher precipitation and subsequent total water storage anomaly, while have a decreased groundwater storage anomaly. Furthermore, GRACE data in the Souss Basin indicates an increase in total water storage $(0.9 \mathrm{~cm} / \mathrm{yr}$.), but a decrease in groundwater storage $(-11.8 \mathrm{~cm} / \mathrm{yr}$.), while the TMPA rainfall shows a constant or slight increase in annual rainfall amounts which suggests human interactions as the underlying cause of depleting groundwater reserves. This is not surprising in Morocco given the over-pumping from 20,000 wells (loss of water: $6.5 \times 10^{8} \mathrm{~m}^{3} / \mathrm{yr}$.) that caused groundwater table drawdown by $0.5 \mathrm{~m}-2.5 \mathrm{~m} / \mathrm{yr}$ within the Souss Basin during the past three decades [38]. These are considered conservative estimates of the effect of pumping given the replacement of freshwater by saltwater in the coastal regions. This would account for greater than $100 \%$ of the recharge in year 2050 and assumes no increase in further abstraction. Second, fundamentally the atmospheric (climate) and hydrologic (groundwater) cycles are linked, the effects are not uniform or constant through time. This provides opportunities and challenges when evaluating the impacts of climate change on groundwater systems worldwide. Due to the presence of uncertainties, errors introduced from input data (e.g., errors in the TRMM precipitation data, errors in the Noah storage estimates) and GRACE errors (e.g., leakage error due to proximity of the study area to the ocean), without verifying the numbers or water storage estimates may not be used directly for water management purposes other than understanding trends and hydrologic processes and variations in the study area. Moreover, recharge and other hydrological and meteorological processes are non-linear and are very sensitive to the timescale used $[105,110]$, and hence, the anthropogenic and climatic impacts on water resources can't be resolved with a simplistic linear separation of both effects. Thus, further research is needed in identifying the non-stationarity, evaluate time-dependent processes involved between these systems, and differentiating between the anthropogenic and climatic impacts on water resources. Third, the effects of climate change go well beyond decreases in precipitation and increases in temperature. Secondary effects such 
as land subsidence, loss of artesian pressure, aquifer collapse, salinization, soil-crusting, salt-water intrusion, and deteriorating water quality have occurred in this area and many others [38,111]. Results highlight the need for further conservation of diminishing groundwater resources and a more complete understanding of the links and impacts of climate change on groundwater reserves.

Author Contributions: A.M. was responsible for project administration, conceptualization of the project, interpreting the results, and manuscript preparation and writing. W.M.S. helped carry out the methodology, processed the GRACE data, analysis, and writing of the manuscript. R.E. aided in the conceptualization of the project, designing the methodology, helping with the hydrologic model, interpreting results, and reviewing the manuscript. M.D. was responsible for the formal analysis, hydrologic model, helped with the climate change simulations, and aided in both writing and editing the manuscript. All authors have read and agreed to the published version of the manuscript.

Funding: The authors would like to thank The University of Georgia Provost Fund for their financial support of the project.

Acknowledgments: Portions of the data used in this effort was acquired as part of the activities of NASA's Science Mission Directorate and are archived and distributed by the Goddard Earth Sciences (GES) Data and Information Services Center (DISC). We would also like to thank the two water basin agencies (L'Agence du Bassin Hydraulique de l'Oum Er Rbia and L'Agence du Bassin Hydraulique du Souss) for providing the streamflow and precipitation data. The authors would also like to thank the anonymous reviewers for their time and help review.

Conflicts of Interest: The authors declare no conflict of interest.

\section{References}

1. UNDESA. Report on the Global Conference on the Sustainable Development in Small Island Developing States; United Nations: New York, NY, USA, 2006.

2. Arnell, N.W. Climate change and global water resources. Glob. Environ. Chang. 1999, 9 (Suppl. S1), S31-S49. [CrossRef]

3. Vörösmarty, J.C. Global water assessment and potential contributions from Earth Systems Science. Aquat. Sci. 2002, 64, 328-351. [CrossRef]

4. Milewski, A.; Sultan, M.; Yan, E.; Becker, R.; Abdeldayem, A.; Soliman, F.; Gelil, K.A. A remote sensing solution for estimating runoff and recharge in arid environments. J. Hydrol. 2009, 373, 1-14. [CrossRef]

5. Oki, T.; Kanae, S. Global Hydrological Cycles and World Water Resources. Science 2006, 313, $1068-1072$. [CrossRef] [PubMed]

6. USAID. Middle East and North Africa Water Center Network; USAID: Washington, DC, USA, 2010.

7. Ireson, A.; Makropoulos, C.; Maksimovic, C. Water Resources Modelling under Data Scarcity: Coupling MIKE BASIN and ASM Groundwater Model. Water Resour. Manag. 2006, 20, 567-590. [CrossRef]

8. Lezzaik, K.; Milewski, A.; Mullen, J. The groundwater risk index: Development and application in the Middle East and North Africa region. Sci. Total Environ. 2018, 628, 1149-1164. [CrossRef]

9. Milewski, A.; Elkadiri, R.; Durham, M. Assessment and Comparison of TMPA Satellite Precipitation Products in Varying Climatic and Topographic Regimes in Morocco. Remote Sens. 2015, 7, 5697-5717. [CrossRef]

10. Milewski, A.; Sultan, M.; Jayaprakash, S.M.; Balekai, R.; Becker, R. RESDEM, a tool for integrating temporal remote sensing data for use in hydrogeologic investigations. Comput. Geosci. 2009, 35, 2001-2010. [CrossRef]

11. Ritzema, H.; Froebrich, J.; Raju, R.; Sreenivas, C.; Kselik, R. Using participatory modelling to compensate for data scarcity in environmental planning: A case study from India. Environ. Model. Softw. 2010, 25, 1450-1458. [CrossRef]

12. Brakensiek, D.L.; Osborn, H.B.; Rawls, W.J. Field manual for research in agricultural hydrology. In Agriculture Handbook; Science and Education Administration, US Department of Agriculture: Washington, DC, USA, 1979.

13. Fetter, C.W. Applied Hydrogeology, 4th ed.; Prentice Hall: Upper Saddle River, NJ, USA, 2001.

14. Lakshmi, V. Remote Sensing of the Terrestrial Water Cycle; John Wiley \& Sons: Hoboken, NJ, USA, 2014; Volume 206.

15. Becker, D.; Sultan, M.; Milewski, A.; Becker, R.; Sauck, W.; Soliman, F.; Rashed, M.; Ahmed, M.; Yan, E.; Wagdy, A.; et al. Integrated solutions for hydrologic investigations in arid lands. Geosphere 2012, 8, 1588-1605. [CrossRef] 
16. Seyoum, W.M.; Milewski, A.M.; Durham, M.C. Understanding the relative impacts of natural processes and human activities on the hydrology of the Central Rift Valley lakes, East Africa. Hydrol. Process. 2015, 29, 4312-4324. [CrossRef]

17. Sultan, M.; Ahmed, M.; Sturchio, N.; Yan, Y.; Milewski, A.; Becker, R.; Wahr, J.; Becker, D.; Chouinard, K. Assessment of the Vulnerabilities of the Nubian Sandstone Fossil Aquifer, North Africa; Elsevier Inc.: Amsterdam, The Netherlands, 2013.

18. Jiang, D.; Wang, K. The Role of Satellite-Based Remote Sensing in Improving Simulated Streamflow: A Review. Water 2019, 11, 1615. [CrossRef]

19. Seyoum, W.M.; Milewski, A.M. Monitoring and comparison of terrestrial water storage changes in the northern high plains using GRACE and in-situ based integrated hydrologic model estimates. Adv. Water Resour. 2016, 94, 31-44. [CrossRef]

20. Xu, X.; Li, J.; Tolson, B.A. Progress in integrating remote sensing data and hydrologic modeling. Prog. Phys. Geogr. 2014, 38, 464-498. [CrossRef]

21. Ahmed, M.; Sultan, M.; Wahr, J.; Yan, E.; Milewski, A.; Sauck, W.; Becker, R.; Welton, B. Integration of GRACE (Gravity Recovery and Climate Experiment) data with traditional data sets for a better understanding of the time-dependent water partitioning in African watersheds. Geology 2011, 39, 479-482. [CrossRef]

22. Al-Dousari, A.M.; Saif, U. Remote sensing inputs to SWAT model for groundwater recharge estimates in Kuwait. Adv. Nat. Appl. Sci. 2010, 4, 71-77.

23. Kehew, A.E.; Milewski, A.; Soliman, F. Reconstructing an extreme flood from boulder transport and rainfall-runoff modelling: Wadi Isla, South Sinai, Egypt. Glob. Planet. Chang. 2010, 70, 64-75. [CrossRef]

24. Sagintayev, Z.; Sultan, M.; Khan, S.D.; Khan, S.A.; Mahmood, K.; Yan, E.; Milewski, A.; Marsala, P. A remote sensing contribution to hydrologic modelling in arid and inaccessible watersheds, Pishin Lora basin, Pakistan. Hydrol. Process. 2011, 26, 85-99. [CrossRef]

25. Ahmed, M.; Wiese, D.N. Short-term trends in Africa's freshwater resources: Rates and drivers. Sci. Total Environ. 2019, 695, 133843. [CrossRef]

26. Lezzaik, K.; Milewski, A. A quantitative assessment of groundwater resources in the Middle East and North Africa region. Hydrogeol. J. 2018, 26, 251-266. [CrossRef]

27. Milewski, A.; Thomas, M.; Seyoum, W.; Rasmussen, T. GRACE-based Groundwater Level Anomalies in the Flint River System, Georgia. Remote Sens. 2019, 11, 2756. [CrossRef]

28. Seyoum, W.M.; Kwon, D.; Milewski, A.M. Downscaling GRACE TWSA Data into High-Resolution Groundwater Level Anomaly Using Machine Learning-Based Models in a Glacial Aquifer System. Remote Sens. 2019, 11, 824. [CrossRef]

29. Mohamed, A.; Sultan, M.; Ahmed, M.; Yan, E.; Ahmed, E. Aquifer recharge, depletion, and connectivity: Inferences from GRACE, land surface models, geochemical, and geophysical data. GSA Bull. 2016, 129, 534-546. [CrossRef]

30. Seyoum, W.M.; Milewski, A.M. Improved methods for estimating local terrestrial water dynamics from GRACE in the Northern High Plains. Adv. Water Resour. 2017, 110, 279-290. [CrossRef]

31. Wehbe, Y.; Ghebreyesus, D.; Temimi, M.; Milewski, A.; Al Mandous, A. Assessment of the consistency among global precipitation products over the United Arab Emirates. J. Hydrol. Reg. Stud. 2017, 12, 122-135. [CrossRef]

32. Lo Conti, F.; Hsu, K.-L.; Noto, L.V.; Sorooshian, S. Evaluation and comparison of satellite precipitation estimates with reference to a local area in the Mediterranean Sea. Atmos. Res. 2014, 138, 189-204. [CrossRef]

33. Moazami, S.; Golian, S.; Kavianpour, M.R.; Hong, Y. Comparison of PERSIANN and V7 TRMM Multi-satellite Precipitation Analysis (TMPA) products with rain gauge data over Iran. Int. J. Remote Sens. 2013, 34, 8156-8171. [CrossRef]

34. Sharifi, E.; Steinacker, R.; Saghafian, B. Assessment of GPM-IMERG and other precipitation products against gauge data under different topographic and climatic conditions in Iran: Preliminary results. Remote Sens. 2016, 8, 135. [CrossRef]

35. Wehbe, Y.; Temimi, M.; Ghebreyesus, D.T.; Milewski, A.; Norouzi, H.; Ibrahim, E. Consistency of precipitation products over the Arabian Peninsula and interactions with soil moisture and water storage. Hydrol. Sci. J. 2018, 63, 408-425. [CrossRef]

36. Zeng, H.; Li, L.; Li, J. The evaluation of TRMM Multisatellite Precipitation Analysis (TMPA) in drought monitoring in the Lancang River Basin. J. Geogr. Sci. 2012, 22, 273-282. [CrossRef] 
37. Ait-Hssaine, A. Mutation d'un espace en bordure du désert par surexploitation de ses ressources hydriques: La dépression du Souss au Maroc/Changes triggered by the over exploitation of water resources in an area bordering the desert: The Souss Valley, Morocco. Rev. De Géographie Alp. 2004, 92, 29-38. [CrossRef]

38. Bouchaou, L.; Michelot, J.; Vengosh, A.; Hsissou, Y.; Qurtobi, M.; Gaye, C.; Bullen, T.; Zuppi, G. Application of multiple isotopic and geochemical tracers for investigation of recharge, salinization, and residence time of water in the Souss-Massa aquifer, southwest of Morocco. J. Hydrol. 2008, 352, 267-287. [CrossRef]

39. Brunner, P.; Hendricks Franssen, H.J.; Kgotlhang, L.; Bauer-Gottwein, P.; Kinzelbach, W. How can remote sensing contribute in groundwater modeling? Hydrogeol. J. 2007, 15, 5-18. [CrossRef]

40. Silliman, S. Development of Reliable Hydrologic Data Sets in Difficult Environments: Case Studies from Benin, West Africa; Darcy Lecturer; NGWA: Westerville, OH, USA, 2011.

41. Sophocleous, M. Global and Regional Water Availability and Demand: Prospects for the Future. Nat. Resour. Res. 2004, 13, 61-75. [CrossRef]

42. Tramblay, Y.; Ruelland, D.; Somot, S.; Bouaicha, R.; Servat, E. High-resolution Med-CORDEX regional climate model simulations for hydrological impact studies: A first evaluation of the ALADIN-Climate model in Morocco. Hydrol. Earth Syst. Sci. 2013, 17, 3721-3739. [CrossRef]

43. Benassi, M. Drought and climate change in Morocco. Analysis of precipitation field and water supply. Options Méditerranéennes 2008, 80, 83-87.

44. García-Ruiz, J.M.; López-Moreno, J.I.; Vicente-Serrano, S.M.; Lasanta-Martínez, T.; Beguería, S. Mediterranean water resources in a global change scenario. Earth Sci. Rev. 2011, 105, 121-139. [CrossRef]

45. Schilling, J.; Freier, K.P.; Hertig, E.; Scheffran, J. Climate change, vulnerability and adaptation in North Africa with focus on Morocco. Agric. Ecosyst. Environ. 2012, 156, 12-26. [CrossRef]

46. d'Oleire-Oltmanns, S.; Marzolff, I.; Peter, K.D.; Ries, J.B.; Aït Hssaïne, A. Monitoring soil erosion in the Souss Basin, Morocco, with a multiscale object-based remote sensing approach using UAV and satellite data. In Proceedings of the 1st World Sustainability Forum; Sciforum Electronic Conference Series; MDPI: Basel, Switzerland, 2011. [CrossRef]

47. Sowers, J.; Vengosh, A.; Weinthal, E. Climate change, water resources, and the politics of adaptation in the Middle East and North Africa. Clim. Chang. 2011, 104, 599-627. [CrossRef]

48. Bouchaou, L.; Tagma, T.; Boutaleb, S.; Hssaisoune, M.; El Morjani, Z.E.A. Climate change and its impacts on groundwater resources in Morocco: The case of the Souss-Massa basin. In Climate Change Effects on Groundwater Resources: A Global Synthesis of Findings and Recommendations; Taylor \& Francis Group: Abingdon, UK, 2011.

49. Ouatiki, H.; Boudhar, A.; Tramblay, Y.; Jarlan, L.; Benabdelouhab, T.; Hanich, L.; El Meslouhi, M.R.; Chehbouni, A. Evaluation of TRMM 3B42 V7 Rainfall Product over the Oum Er Rbia Watershed in Morocco. Climate 2017, 5, 1. [CrossRef]

50. Schyns, J.F.; Hoekstra, A.Y. The Added Value of Water Footprint Assessment for National Water Policy: A Case Study for Morocco. PLoS ONE 2014, 9, e99705. [CrossRef] [PubMed]

51. Huffman, G.J.; Bolvin, D.T.; Nelkin, E.J.; Wolff, D.B.; Adler, R.F.; Gu, G.; Hong, Y.; Bowman, K.P.; Stocker, E.F. The TRMM Multisatellite Precipitation Analysis (TMPA): Quasi-Global, Multiyear, Combined-Sensor Precipitation Estimates at Fine Scales. J. Hydrometeorol. 2007, 8, 38-55. [CrossRef]

52. Rodell, M.; Houser, P.R. Updating a Land Surface Model with MODIS-Derived Snow Cover. J. Hydrometeorol. 2004, 5, 1064-1075. [CrossRef]

53. Wahr, J.; Molenaar, M.; Bryan, F. Time variability of the Earth's gravity field: Hydrological and oceanic effects and their possible detection using GRACE. J. Geophys. Res. Solid Earth 1998, 103, 30205-30229. [CrossRef]

54. Houborg, R.; Rodell, M.; Li, B.; Reichle, R.; Zaitchik, B.F. Drought indicators based on model-assimilated Gravity Recovery and Climate Experiment (GRACE) terrestrial water storage observations. Water Resour. Res. 2012, 48. [CrossRef]

55. Rodell, M.; Velicogna, I.; Famiglietti, J.S. Satellite-based estimates of groundwater depletion in India. Nature 2009, 460, 999-1002. [CrossRef]

56. Swenson, S.; Wahr, J. Monitoring the water balance of Lake Victoria, East Africa, from space. J. Hydrol. 2009, 370, 163-176. [CrossRef]

57. Feng, W.; Zhong, M.; Lemoine, J.-M.; Biancale, R.; Hsu, H.-T.; Xia, J. Evaluation of groundwater depletion in North China using the Gravity Recovery and Climate Experiment (GRACE) data and ground-based measurements. Water Resour. Res. 2013, 49, 2110-2118. [CrossRef] 
58. Landerer, F.; Swenson, S. Accuracy of scaled GRACE terrestrial water storage estimates. Water Resour. Res. 2012, 48. [CrossRef]

59. Swenson, S.; Wahr, J. Post-processing removal of correlated errors in GRACE data. Geophys. Res. Lett. 2006, 33. [CrossRef]

60. Chen, J.; Li, J.; Zhang, Z.; Ni, S. Long-term groundwater variations in Northwest India from satellite gravity measurements. Glob. Planet. Chang. 2014, 116, 130-138. [CrossRef]

61. Joodaki, G.; Wahr, J.; Swenson, S. Estimating the human contribution to groundwater depletion in the Middle East, from GRACE data, land surface models, and well observations. Water Resour. Res. 2014, 50, 2679-2692. [CrossRef]

62. Konikow, L.F. Long-Term Groundwater Depletion in the United States. Groundwater 2015, 53, 2-9. [CrossRef] [PubMed]

63. Ek, M.B.; Mitchell, K.E.; Lin, Y.; Rogers, E.; Grunmann, P.; Koren, V.; Gayno, G.; Tarpley, J.D. Implementation of Noah land surface model advances in the National Centers for Environmental Prediction operational mesoscale Eta model. J. Geophys. Res. Atmos. 2003, 108. [CrossRef]

64. Seyyedi, H.; Anagnostou, E.N.; Beighley, E.; McCollum, J. Satellite-driven downscaling of global reanalysis precipitation products for hydrological applications. Hydrol. Earth Syst. Sci. 2014, 18, 5077-5091. [CrossRef]

65. Arnold, J.G.; Srinisvan, R.; Muttiah, R.S.; Williams, J.R. Large Area Hydrologic Modeling and Assessment, Part I: Model Development. J. Am. Water Resour. Assoc. 1998, 34, 73-89. [CrossRef]

66. Arnold, J.G.; Fohrer, N. SWAT2000: Current capabilities and research opportunities in applied watershed modelling. Hydrol. Process. 2005, 19, 563-572. [CrossRef]

67. Chaponnière, A.; Boulet, G.; Chehbouni, A.; Aresmouk, M. Understanding hydrological processes with scarce data in a mountain environment. Hydrol. Process. 2008, 22, 1908-1921. [CrossRef]

68. Gassman, P.W.; Reyes, M.R.; Green, C.H.; Arnold, J.G. The Soil and Water Assessment Tool: Historical Development, Applications, and Future Research Directions; Center for Agricultural and Rural Development, Iowa State University: Heady Hall, IA, USA, 2007.

69. Hernandez, M.; Miller, S.N.; Goodrich, D.C.; Goff, B.F.; Kepner, W.G.; Edmonds, C.M.; Jones, K.B. Modeling runoff response to land cover and rainfall spatial variability in semi-arid watersheds. In Monitoring Ecological Condition in the Western United States; Springer: Berlin/Heidelberg, Germany, 2000; pp. 285-298.

70. Muttiah, R.S.; Wurbs, R.A. Scale-dependent soil and climate variability effects on watershed water balance of the SWAT model. J. Hydrol. 2002, 256, 264-285. [CrossRef]

71. Neitsch, S.L.; Williams, J.; Arnold, J.; Kiniry, J. Soil and Water Assessment Tool Theoretical Documentation, version 2009; Texas Water Resources Institute: College Station, TX, USA, 2011.

72. FAO; ISRIC; JRC. Harmonized World Soil Database, version 1.2; FAO: Rome, Italy; IIASA: Laxenburg, Austria, 2014.

73. Saha, S.; Moorthi, S.; Pan, H.; Wu, X.; Wang, J.; Nadiga, S.; Tripp, P.; Kistler, R.; Woollen, J.; Behringer, D. NCEP Climate Forecast System Reanalysis (CFSR) 6-Hourly Products, January 1979 to December 2010; The National Center for Atmospheric Research, Computational and Information Systems Laboratory: Boulder, CO, USA, 2010.

74. SCS. SCS National Engineering Handbook, Section 4: Hydrology; United States Soil Conservation Service: Washington, DC, USA, 1972.

75. SCS. SCS Engineering Field Manual; US Department of Agriculture: Washington, DC, USA, 1984.

76. Gheith, H.; Sultan, M. Construction of a hydrologic model for estimating Wadi runoff and groundwater recharge in the Eastern Desert. Egypt J. Hydrol. 2002, 263, 36-55. [CrossRef]

77. Osterkamp, W.R.; Lane, L.J.; Savard, C.S. Recharge estimates using a geomorphic/distributed-parameter simulation approach, amargosa rwer basin1. JAWRA 1994, 30, 493-507.

78. Burn, D.H.; Boorman, D.B. Estimation of hydrological parameters at ungauged catchments. J. Hydrol. 1993, 143, 429-454. [CrossRef]

79. Kokkonen, T.S.; Jakeman, A.J.; Young, P.C.; Koivusalo, H.J. Predicting daily flows in ungauged catchments: Model regionalization from catchment descriptors at the Coweeta Hydrologic Laboratory, North Carolina. Hydrol. Process. 2003, 17, 2219-2238. [CrossRef]

80. Pilgrim, D.H. Some problems in transferring hydrological relationships between small and large drainage basins and between regions. J. Hydrol. 1983, 65, 49-72. [CrossRef] 
81. Abbaspour, K.C. User Manual for SWAT-CUP, SWAT Calibration and Uncertainty Analysis Programs; Swiss Federal Institute of Aquatic Science and Technology: Duebendorf, Switzerland, 2012.

82. Arnold, J.G.; Moriasi, D.N.; Gassman, P.W.; Abbaspour, K.C.; White, M.J.; Srinivasan, R.; Santhi, C.; Harmel, R.; Van Griensven, A.; Van Liew, M.W. SWAT: Model use, calibration, and validation. Trans. ASABE 2012, 55, 1491-1508. [CrossRef]

83. Jimeno-Sáez, P.; Senent-Aparicio, J.; Pérez-Sánchez, J.; Pulido-Velazquez, D. A Comparison of SWAT and ANN Models for Daily Runoff Simulation in Different Climatic Zones of Peninsular Spain. Water 2018, 10, 192. [CrossRef]

84. Moriasi, D.; Arnold, J.; Liew, M.; Bingner, R.; Harmel, R.; Veith, T. Model Evaluation Guidelines for Systematic Quantification of Accuracy in Watershed Simulations. Trans. ASABE 2007, 50, 885-900. [CrossRef]

85. Van Liew, M.W.; Veith, T.L.; Bosch, D.D.; Arnold, J.G. Suitability of SWAT for the Conservation Effects Assessment Project: Comparison on USDA Agricultural Research Service Watersheds. J. Hydrol. Eng. 2007, 12, 173-189. [CrossRef]

86. Kalin, L.; Isik, S.; Schoonover, J.E.; Lockaby, B.G. Predicting Water Quality in Unmonitored Watersheds Using Artificial Neural Networks. J. Environ. Qual. 2010, 39, 1429-1440. [CrossRef]

87. Warrick, R.; Ye, W.; Kouwenhoven, P.; Hay, J.; Cheatham, C. New Developments of the SimCLIM Model for Simulating Adaptation to Risks Arising from Climate Variability and Change. In MODSIM 2005; Zerger, A., Argent, R.M., Eds.; Modelling and Simulation, Modelling and Simulation Society of Australia and New Zealand: Canberra, Australia, 2005.

88. IPCC. Climate Change 2014: Impacts, Adaptation, and Vulnerability. Part A: Global and Sectoral Aspects. In Contribution of Working Group II to the Fifth Assessment Report of the Intergovernmental Panel on Climate Change; Cambridge University Press: Cambridge, UK, 2014.

89. Taylor, K.E.; Stouffer, R.J.; Meehl, G.A. An overview of CMIP5 and the experiment design. Bull. Am. Meteorol. Soc. 2012, 93, 485. [CrossRef]

90. Moss, R.H.; Edmonds, J.A.; Hibbard, K.A.; Manning, M.R.; Rose, S.K.; van Vuuren, D.P.; Carter, T.R.; Emori, S.; Kainuma, M.; Kram, T.; et al. The next generation of scenarios for climate change research and assessment. Nature 2010, 463, 747-756. [CrossRef] [PubMed]

91. Rogelj, J.; Meinshausen, M.; Knutti, R. Global warming under old and new scenarios using IPCC climate sensitivity range estimates. Nat. Clim. Chang. 2012, 2, 248-253. [CrossRef]

92. Urich, P.; Kouwenhoven, P.; Freas, K.; van der Tak, L. New IPCC climate models released: Understanding the planning implications for water resiliency (PDF). J. Am. Water Work. Assoc. 2014, 106, 51-60. [CrossRef]

93. van Vuuren, D.P.; Edmonds, J.; Kainuma, M.; Riahi, K.; Thomson, A.; Hibbard, K.; Hurtt, G.C.; Kram, T.; Krey, V.; Lamarque, J.-F.; et al. The representative concentration pathways: An overview. Clim. Chang. 2011, 109, 5-31. [CrossRef]

94. Amin, A.; Mubeen, M.; Hammad, H.; Nasim, W. Climate Smart Agriculture-a solution for sustainable future. Agric. Res. Commun 2015, 2, 13-21.

95. Carter, T.R. Developing and Applying Scenarios, Chapter 3 in Climate Change 2001: Impacts, Adaptation, and Vulnerability. In The IPCC WG 2 Third Assessment Report; Cambridge University Press: Cambridge, UK, 2001.

96. Hulme, M.; Wigley, T.M.; Barrow, E.; Raper, S.; Centella, A.; Smith, S.; Chipanshi, A. Using A Climate Scenario Generator for Vulnerability and Adaptation Assessments: MAGICC AND SCENGEN: Version 2.4 Workbook; Climatic Research Unit: Norwich, UK, 2000; p. 52.

97. Santer, B.D.; Wigley, T.M.; Schlesinger, M.E.; Mitchell, J.F. Developing climate scenarios from equilibrium GCM results. In Max-Planck-Institut für Meteorologie Report; Max Planck Institute for Meteorology: Hamburg, Germany, 1990.

98. Coquard, J.; Duffy, P.; Taylor, K.; Iorio, J. Present and future surface climate in the western USA as simulated by 15 global climate models. Clim. Dyn. 2004, 23, 455-472. [CrossRef]

99. Amin, A.; Nasim, W.; Mubeen, M.; Kazmi, D.H.; Lin, Z.; Wahid, A.; Sultana, S.R.; Gibbs, J.; Fahad, S. Comparison of future and base precipitation anomalies by SimCLIM statistical projection through ensemble approach in Pakistan. Atmos. Res. 2017, 194, 214-225. [CrossRef] 
100. Brahim, Y.A.; Seif-Ennasr, M.; Malki, M.; N’da, B.; Choukrallah, R.; El Morjani, Z.E.A.; Sifeddine, A.; Abahous, H.; Bouchaou, L. Assessment of Climate and Land Use Changes: Impacts on Groundwater Resources in the Souss-Massa River Basin. In The Souss-Massa River Basin; Springer International Publishing: Cham, Switzerland, 2017; pp. 121-142.

101. Filahi, S.; Tanarhte, M.; Mouhir, L.; El Morhit, M.; Tramblay, Y. Trends in indices of daily temperature and precipitations extremes in Morocco. Theor. Appl. Climatol. 2016, 124, 959-972. [CrossRef]

102. Hssaisoune, M.; Boutaleb, S.; Benssaou, M.; Bouaakkaz, B.; Bouchaou, L. Physical Geography, Geology, and Water Resource Availability of the Souss-Massa River Basin. In The Souss-Massa River Basin; Springer International Publishing: Cham, Switzerland, 2017; pp. 27-56.

103. N'da, A.B.; Bouchaou, L.; Reichert, B.; Hanich, L.; Brahim, Y.A.; Chehbouni, A.; Beraaouz, E.H.; Michelot, J.-L. Isotopic signatures for the assessment of snow water resources in the Moroccan high Atlas mountains: Contribution to surface and groundwater recharge. Environ. Earth Sci. 2016, 75, 755. [CrossRef]

104. Knutti, R.; Abramowitz, G.; Collins, M.; Eyring, V.; Gleckler, P.J.; Hewitson, B.; Mearns, L. Good Practice Guidance Paper on Assessing and Combining Multi Model Climate Projections. In Meeting Report of the Intergovernmental Panel on Climate Change Expert Meeting on Assessing and Combining Multi Model Climate Projections; Stocker, T.F., Qin, D., Plattner, G.-K., Tignor, M., Midgley, P.M., Eds.; IPCC Working Group I Technical Support Unit, University of Bern: Bern, Switzerland, 2010.

105. Pulido-Velazquez, D.; García-Aróstegui, J.L.; Molina, J.L.; Pulido-Velazquez, M. Assessment of future groundwater recharge in semi-arid regions under climate change scenarios (Serral-Salinas aquifer, SE Spain). Could increased rainfall variability increase the recharge rate? Hydrol. Process. 2015, 29, 828-844. [CrossRef]

106. Pulido-Velazquez, M.; Alvarez-Mendiola, E.; Andreu, J. Design of Efficient Water Pricing Policies Integrating Basinwide Resource Opportunity Costs. J. Water Resour. Plan. Manag. 2013, 139, 583-592. [CrossRef]

107. Pulido-Velazquez, M.; Andreu, J.; Sahuquillo, A.; Pulido-Velazquez, D. Hydro-economic river basin modelling: The application of a holistic surface-groundwater model to assess opportunity costs of water use in Spain. Ecol. Econ. 2008, 66, 51-65. [CrossRef]

108. Nicholson, S.E. The nature of rainfall variability over Africa on time scales of decades to millenia. Glob. Planet. Chang. 2000, 26, 137-158. [CrossRef]

109. Speth, P.; Christoph, M.; Diekkrüger, B. Impacts of Global Change on the Hydrological Cycle in West and Northwest Africa; Springer Science \& Business Media: Berlin, Germany, 2010.

110. Pulido-Velazquez, D.; Garrote, L.; Andreu, J.; Martin-Carrasco, F.-J.; Iglesias, A. A methodology to diagnose the effect of climate change and to identify adaptive strategies to reduce its impacts in conjunctive-use systems at basin scale. J. Hydrol. 2011, 405, 110-122. [CrossRef]

111. Malki, M.; Bouchaou, L.; Hirich, A.; Brahim, Y.A.; Choukr-Allah, R. Impact of agricultural practices on groundwater quality in intensive irrigated area of Chtouka-Massa, Morocco. Sci. Total Environ. 2017, 574, 760-770. [CrossRef]

(C) 2019 by the authors. Licensee MDPI, Basel, Switzerland. This article is an open access article distributed under the terms and conditions of the Creative Commons Attribution (CC BY) license (http://creativecommons.org/licenses/by/4.0/). 